\title{
THE ROLE OF INFORMATION FOR RETIREMENT BEHAVIOR: EVIDENCE BASED ON THE STEPWISE INTRODUCTION OF THE SOCIAL SECURITY STATEMENT
}

\author{
Giovanni Mastrobuoni*
}

CRR WP 2009-23

Released: October 2009

Draft Submitted: October 2009

\author{
Center for Retirement Research at Boston College \\ Hovey House \\ 140 Commonwealth Avenue \\ Chestnut Hill, MA 02467
}

Tel: 617-552-1762 Fax: 617-552-0191

\begin{abstract}
* Giovanni Mastrobuoni is an assistant professor at the Collegio Carlo Alberto and CeRP. The research reported herein was pursuant to a grant from the U.S. Social Security Administration (SSA) funded as part of the Retirement Research Consortium (RRC). The opinions and conclusions expressed are solely those of the author and do not represent the opinions of SSA, any agency of the Federal Government, the Collegio Carlo Alberto, CeRP, the RRC, or Boston College. Wioletta Dziuda has been of invaluable help. I would also like to thank Orley Ashenfelter, Raj Chetty, Bo Honor'e, Alan Krueger, Harvey Rosen, and all participants at the Labor seminar, the Public Finance seminar, and the Office of Research seminar at the Social Security Administration, in particular Jane Fortson, Radha Iyengar, Joyce Manchester, Nisreen Salti, Martin Schonger, Perry Singleton, David Weaver, Matt Weinberg, and Luke Willard. A special thanks goes to Jae Song, who provided the data, an initial benefit calculator, and also organized my first summer stay at the Social Security Administration.

(C) 2009, by Giovanni Mastrobuoni. All rights reserved. Short sections of text, not to exceed two paragraphs, may be quoted without explicit permission provided that full credit, including (C) notice, is given to the source.
\end{abstract}




\title{
About the Center for Retirement Research
}

The Center for Retirement Research at Boston College, part of a consortium that includes parallel centers at the University of Michigan and the National Bureau of Economic Research, was established in 1998 through a grant from the Social Security Administration. The Center's mission is to produce first-class research and forge a strong link between the academic community and decision makers in the public and private sectors around an issue of critical importance to the nation's future. To achieve this mission, the Center sponsors a wide variety of research projects, transmits new findings to a broad audience, trains new scholars, and broadens access to valuable data sources.

\author{
Center for Retirement Research at Boston College \\ Hovey House \\ 140 Commonwealth Avenue \\ Chestnut Hill, MA 02467 \\ phone: 617-552-1762 fax: 617-552-0191 \\ e-mail: crr@bc.edu \\ www.bc.edu/crr
}

Affiliated Institutions:

The Brookings Institution

Massachusetts Institute of Technology

Syracuse University

Urban Institute 


\begin{abstract}
In 1995, the Social Security Administration started sending out the annual Social Security Statement. It contains information about the worker's estimated benefits at the ages 62, 65, and 70. I use this unique natural experiment to analyze the retirement and claiming decision-making. First, I find that, despite the previous availability of information, the Statement has a significant impact on workers' knowledge about their benefits. These findings are consistent with a model where workers need to gather costly information in order to improve their retirement decision. Second, I use this exogenous variation in knowledge to analyze the optimality of workers' decisions. Several findings suggest that workers do not change their retirement behavior: i) Workers do not change their expected age of retirement after receiving the Statement; ii) monthly claiming patterns do not show any change after the introduction of the Social Security Statement; iii) workers do not become more sensitive to Social Security incentives after receiving the Statement. Either, workers are already behaving optimally, or the information contained in the Statement is not sufficient to improve their retirement behavior.
\end{abstract}




\section{Introduction}

Many older workers know little about their retirement benefits and do not plan ahead 1 In order to help workers make provisions for their retirement, the Social Security Administration (SSA) introduced the Social Security Statement in 1995. The Statement is a concise record of past earnings and a summary of estimated benefits as a function of different retirement ages. It is mailed to all workers paying payroll taxes, typically three months before their birthday. While in 2008 the cost of sending an individual Statement was only about 36 cents, the huge number of statements sent each year results in a total cost of sending the Statements of 53 million dollars (SSAB, 2009). This paper evaluates whether sending the Statement increased workers' knowledge and influenced retirement behavior.

In 1995 the SSA was required to mail the annual Statement - then named the Personal Earnings and Benefit Estimate Statement - to all workers age 60 and older and in later years it has been sent according to the following (year, age) combinations: (1996, 58+), (1997, 53+), (1998, 47+), (1999, 44+), (2000, 25+). This stepwise introduction allows me to identify the effect of the Statement based on the interaction between age and year. Using The Health and Retirement Survey (HRS) data, I find that workers aged 55 to 64 who received the Statement and had not previously contacted SSA regarding their benefits are 20 percentage points (50 percent) more likely to be able to provide an estimate of their future benefits than workers that did not receive the Statement.

While these a very large effects, if workers were behaving optimally this additional information would not substantially change workers' retirement or saving behavior. On the other hand, some workers might just be procrastinating: the cost of becoming informed and learning when best to retire and how much to save are borne upfront, while the corresponding utility gains are received only sometime later. Workers with high discount rates should, therefore, get informed later. For these workers, the Social Security Statement might actually induce changes in behavior. I use three different ways to measure changes in behavior. First, I look at whether workers are more likely to update their retirement plans upon receiving a Statement. Then, I check whether workers change their actual claiming behavior. Finally, I see whether workers are more likely to respond to the retirement incentives provided by the Social Security benefit formula after receiving a Statement 2

I find no evidence that receiving the first Statement induces workers to update their expectations. Social Security claiming patterns also show no change upon the introduction of the Statement. Retirement decisions do not become more sensitive to Social Security incentives. Overall, the results suggest that either workers were already behaving optimally or that the additional information provided by the

\footnotetext{
${ }^{1}$ See among others, Bernheim and Levin (1989), Gustman and Steinmeier (2001), Chan and Stevens (2008), Lusardi and Mitchell (2006), Lusardi and Mitchell (2007).

${ }^{2}$ The administrative records are used to compute retirement incentives (see, for example, Coile and Gruber, 2007, Liebman et al., n.d., Panis et al., 2002).
} 
Statement isn't sufficient to improve uniformed workers' retirement choices.

\section{Literature review}

\subsection{Retirement Behavior}

Standard economic theory assumes that all agents base their retirement decisions on forward-looking variables. Krueger and Meyer (2002) provide a comprehensive survey of studies that have modeled retirement behavior. These studies typically assume implicitly that workers know their future benefits as a function of their retirement age and are able to compare future streams of benefits. Empirical evidence, however, suggests that these are strong assumptions. When asked, only around 50 percent provide an estimate of their expected Social Security benefits 3 Gustman and Steinmeier (2001) show that less than 30 percent of respondents are able to estimate their future benefits to within about $\$ 1,500$ per year. Moreover, Lusardi and Mitchell (2006) show that financial illiteracy is widespread among older Americans. Only half of the age 50+ respondents can correctly answer two simple questions regarding interest compounding and inflation. Is it then reasonable to assume those same respondents are able to compute their retirement incentives, which typically involve relatively complex calculations?

Despite very little knowledge about retirement incentives, the fact that people seem to respond to incentives when making their retirement decisions has been called by Chan and Stevens (2008) an "important empirical puzzle in the retirement literature." Gustman and Steinmeier (2001) try to test the robustness of retirement models when a measure of knowledge about benefits is added to the retirement regression. They find that explicitly controlling for knowledge does not affect workers' responsiveness to changes in the present value of the stream of Social Security benefits from postponing retirement, which are also called accruals. Chan and Stevens (2008) go one step further and analyze how the interaction of knowledge and accruals affects workers' decisions. The authors find that responsiveness to pension incentives is entirely driven by the 20 percent of workers who perceive them correctly 4 The validity of using measures of knowledge in the regressions, however, is questionable as knowledge is endogenous: workers gather information when they approach their expected retirement age. Most workers contact the SSA in order to learn about their future Social Security benefits. Once they do so, the data show that they become more likely to provide a benefit es-

\footnotetext{
${ }^{3}$ See Bernheim and Levin (1989), Gustman and Steinmeier (2001). In my sample that focuses on workers aged 55 and above, two-thirds of workers are able to provide an estimate.

${ }^{4}$ They do not find any link between knowledge and Social Security accruals, which they consider a result of data limitations. A limitation of their test, and as a matter of fact, of mine as well, is that they can measure if workers correctly perceive their Social Security benefits, but not if they correctly compute their forward-looking Social Security incentives, like the presentdiscounted stream of benefits.
} 
timate, and their estimate becomes more precise 5 This is not surprising. The SSA's benefit formula is complicated, and workers would have a hard time trying to calculate their expected benefits without the SSA's help. But to value this additional information workers need to be able to use it and need to be unconstraint with respect to their retirement choice, i.e. workers who face health problems or are liquidity constraints tend to retire as soon as possible. Consistent with this, I find that wealthier and healthier workers are significantly more likely to get informed. A more puzzling finding is that even after controlling for labor market experience, occupation, wealth, and health, black workers and workers with low levels of education are significantly less likely to know their benefits. One possible explanation for this persistent gap is that these workers are also more likely to be financially illiterate (Lusardi and Mitchell, 2006).

\subsection{The Social Security Statement}

Beside the Government Accountability Office (GAO) that has tried to evaluate their understandability, economists have not paid much attention to the introduction of the Statements 6 This has prompted Jackson (2005) to conclude that: "Given the importance of Social Security benefits to so many Americans, it is surprising how little academic attention has been given to the content and implications of Social Security benefits" and "..., what is clear is that the Social Security Statement is one of the most important communication that the federal government sends out to the general public each year, and as such the document deserves much more attention from public official and academic writers than it has received to date." According to the GAO reports the overall public reaction to receiving an unsolicited Statement has been favorable. The reports cite a nationally representative survey in which, as predicted by Bernheim (1987), "the majority of the respondents indicated they were glad to receive their Statements and 95 percent of them said the information provided was helpful to their families." The April 2005 report finds that 66 percent of workers remember receiving a Statement (unfortunately they do not provide this number by age groups), and that 90 percent of those who remember receiving a Statement say that they remember the amount of estimated Social Security benefits. The results of a Gallup survey, undertaken at the request of the SSA, revealed that individuals who had received a Statement had a significantly increased basic understanding of Social Security, and an increased understanding of some important basic features of Social Security: the amount of Social Security benefits depends on how much people earned; Social Security pays benefits to workers who become disabled; Social Security provides benefits to dependents of workers who die (see http://www.ssa.gov/) According

\footnotetext{
5 Gustman and Steinmeier (2001) show that having contacted the SSA is the strongest predictor for being knowledgeable about Social Security benefits.

${ }^{6}$ See GAO/T-HEHS-96-210, GAO/HEHS-97-19, GAO/HEHS-98-228, GAO/T-HEHS-00-101, GAO-05-192 on www.gao.gov.
} 
to the 2004 Retirement Confidence Survey, 80 percent of workers use retirement benefit Statements (not necessarily only Social Security Statements) and 20 percent find them the most helpful tool in retirement and claiming decision making (Helman and Paladino, 2004). Jackson analyzes the content of the Social Security Statement, and reports how because of various cognitive biases workers may misinterpret the value of their benefits. He then suggests that including the present discounted value of Social Security benefits may facilitate the comparison with other sources of income and minimize labor market distortions.

\section{Exogenous Variation in Knowledge}

\subsection{The Phasing In Schedule of the Statement}

The administration started sending the Statements in 1995. The main purpose is to inform the public about benefits under SSA programs, to aid in financial planning, and to ensure the worker's earnings records are complete and accurate. The Statement contains expected Social Security benefits at the early (62), the normal (usually 65, though increasing since 2003), and the late (70) retirement age as well as the worker's entire earnings history. The Statement also informs workers about spouse's benefits, survivors' benefits, and disability benefits.7 The Statement does not report the present discounted value of these benefits, also called the Social Security Wealth (SSW).

The SSA was required to mail the annual Statement - then named the Personal Earnings and Benefit Estimate Statement - to all workers age 60 and older. In later years it has been sent according to the following (year, age) combinations: $(1996,58+),(1997,53+),(1998,47+),(1999,44+),(2000,25+)$. Workers usually receive their Statement one month before their birthdays 8 This seems to be a good timing since 65 percent of all workers claim immediately after their birthdays (15 percent of the claims occur in January and the remaining workers tend to claim uniformly across the year). Later I show that apart from age and year no other observable characteristics of workers are able to predict the receipt of a Statement. Conditional on age and year effects it is as if it was randomly assigned. With precise information on the date of the HRS surveys and on the date of birth of the respondents and with internal documents of the SSA I reconstruct the exact same schedule used by the Social Security Administration to sent out the letters. Table 1 shows, based on a hypothetical sample (where age and year of birth are uniformly distributed) the fraction of workers who over the years would have received a Statement. Later I will exploit the fact that workers of the same age (in years) may or may not receive a Statement in the same year.

\footnotetext{
${ }^{7}$ In the Appendix provide a sample of the Social Security Statement. Earlier versions of the Statement can be found in reports by the GAO, although they changed little over time.

${ }^{8}$ In 2000 the SSA started sending the Statement three months before the worker's birthday.
} 


\subsection{The Statement's Impact on Workers' Knowledge About Benefits}

Assuming that getting informed is costly, a worker will acquire new information about his retirement benefits when, based on his prior $f(B)$ over the whole distribution of his retirement benefits (which are function of the retirement age $B=$ $(B(62), \ldots, B(70))$ he/she believes that the expected gains of information outweigh the cost of information, $c$. Retirement affects utility through its consequences on consumption and leisure. Defining the retirement decision as $R \in\{0,1\}$, it's optimal to gather information as long as

$$
\int \max _{R} U[R(B)] f(B) d B-\max _{R} \int U[R(B)] f(B) d B>c .
$$

Intuitively, information matters when better knowledge about the benefits can influence retirement or consumption, in other words, when variation in benefit patterns generate variations in utility $U[R(B)]$. If, for example, the prior is such that the worker strongly believes that it is optimal to retire as soon as possible, it might not be optimal for him to collect additional information. Factors that can generate such a boundary solution are high discount rates, high disutility from work (like health issues), high mortality, and low risk aversion. Moreover, workers need to be able to evaluate their retirement incentives, which are complicated functions of their benefits and of their family status. Financially illiterate workers, unable to compute those incentives, might also choose not to get informed.

The main effect of the Statement is to considerably reduce $c$, which should help workers to make better retirement choices. But if workers select into the unknowledgeable state changes in retirement behavior are expected to be lower than in a situation where knowledge was randomly assigned. It is important to note that workers have always had the option to ask the SSA to compute their expected benefits (it would usually take 4 to 6 weeks to receive an estimate). Before the Statements started circulating according to the HRS around 50 percent of the respondents would contact the SSA by age 62 . Before analyzing the effect of the Statement it is therefore important to analyze the selection issue (calling the SSA for a benefit estimate) 9

Column (1) in Table 2 shows that, apart from age (multiplied by $1 / 2$ for a reason that will be clear shortly), the two strongest predictors for contacting the SSA are the level of education and race. Having less than a high school degree and being black, reduce the probability of contacting the SSA by 14 and 11 percentage points. Consistent with the theory wealthier workers, therefore workers that are less likely to be liquidity constraint, are more likely to contact the SSA (column 2 ). The effects are very large. Compared to workers that are in the first wealth quartile, workers with wealth above the median are 17 to 19 percentage points

\footnotetext{
${ }^{9}$ See Appendix $\AA$ for a description of the data and for the corresponding summary statistics.
} 
more likely to contact the SSA. Healthy workers are, compared to workers in fair and poor health, more likely to contact the SSA. Health and wealth do also capture around 30 percent of the differences that in the first column were attributed to race and education.

In column (3) I additionally control for the subjective life-expectancy and for labor market experience 10 While more experienced workers are significantly more likely to contact the SSA, the coefficient on the subjective life-expectancy is not significant. Since the SSA's actuarial adjustments for postponing retirement are based on the average life-expectancy workers with a low subjective life-expectancy should be less likely to get informed if they know that they should follow the simple rule of retiring and claiming the benefits as soon as possible. On the other hand, workers with a high life-expectancy should do the opposite, claim as late as possible (70). Checking for non-linearities does reveal that workers in the first and the last quartile of the distribution of subjective life-expectancy are less likely to get informed, but the effects are not significant 11

Around 35 percent of workers age 65 receive a private pension. The incentives of getting informed might differ by whether workers receive a pension or participate in a defined benefit or defined contribution plan, both because pensions change the liquidity constraint and because pensions change the overall retirement incentives. Receiving a pension and participating in a pension plan do not significantly change the probability of contacting the SSA, even when I focus on those who do not yet receive a pension income 12

In column (5) I control for the respondents financial planning time horizon, information available from the HRS's first wave. How far in advance workers are planning is certainly related to their time preference. Consistent with this I find that the longer the planning time horizon the more likely it is workers contact the SSA. It is important to notice that even after controlling for health, wealth, mortality, and proxies of time preference workers without a high school degree and black workers are 10 percentage points less likely to contact the SSA. In the last column I additionally control for occupation fixed effects. While this reduces by another 30 percent the differences across levels of education, the coefficient on race drops by only 1 percentage point.

Summing up, workers who didn't contact the SSA before the introduction of the Statement tend to be younger, with lower levels of education, single, black, in poor health, poor, with fewer labor market experience, and less likely to plan many years in advance. Next I show that these workers are more likely to improve their knowledge about their benefits upon receiving a Statement, which is consistent with the idea that information is costly.

\footnotetext{
${ }^{10}$ The subjective life-expectancy is measured as the self-reported probability of surviving age 75 divided by the implied probability from the Vital Statistics life tables that someone of the respondent's age and gender will live to be 75 .

${ }^{11}$ Results available upon request.

${ }^{12}$ The sample size is lower because the information on whether the respondent receives a pension isn't available in the first wave.
} 


\subsection{The Effect of the Statement on Workers' Knowledge about Retirement Benefits}

In all six available waves of the HRS (1992-2002), workers are asked about their expected retirement age and their expected Social Security benefits 13 In the absence of any informational cost we would expect the Statement to have a negligible effect on workers' knowledge.

Column (1) in Table 3 shows the effect of the Statement on the probability of reporting Social Security benefits 14 estimated using a linear probability model. I control for age, age squared, year, gender, level of education, marital status, race, and labor market experience (number of years with positive earnings). When I control for a quadratic term of age and a linear term for years the introduction of the Statement reduces the probability of not reporting an estimate by 4.29 percentage points. Controlling for age, year, and wealth and health fixed effects (column 2) doesn't alter the effects, apart from being less significant. This 15 percent drop in the probability of being uniformed can be interpreted as an average treatment effect. Being black and not having a high school degree are both very strong predictors for not knowing the future amount of the benefits.

In order to evaluate the effect of the Statement on workers who didn't contact the SSA before receiving the Statement I need to control for the fact that some workers would have shown an improvement even without the Statement (they would have contacted the SSA). Define the event "contacting SSA" as $C \in\{0,1\}$ and "not being able to provide an estimate" as $N \in\{0,1\}$. I need to estimate the improvement in $\operatorname{Pr}(N=1)$ that would have happened independently of the Statement $T \in\{0,1\}: \operatorname{Pr}\left(N_{t}=1 \mid C_{t-2}=0, T=0\right)-\operatorname{Pr}\left(N_{t-2}=1 \mid C_{t-2}=0, T=\right.$ 0 ). Having in mind that I'm always conditioning on $T=0$, by the law of total probability: $\operatorname{Pr}\left(N_{t}=1 \mid C_{t-2}=0\right)=\operatorname{Pr}\left(N_{t}=1 \mid C_{t}=0\right) \operatorname{Pr}\left(C_{t}=0 \mid C_{t-2}=0\right)+$ $\operatorname{Pr}\left(N_{t}=1 \mid C_{t}=1\right) \operatorname{Pr}\left(C_{t}=1 \mid C_{t-2}=0\right)$. One way to estimate $\operatorname{Pr}\left(C_{t}=1 \mid C_{t-2}=0\right)$ is to use the cross-sectional information using age as a measure of time. Our estimate of $\operatorname{Pr}\left(C_{t}=1 \mid C_{t-2}=0\right)$ is going to be equal to the coefficient on age $\times 1 / 2$ from Table 2. Age is multiplied by $1 / 2$ in order to estimate the probability over a 2-year period (the HRS is biennial). When I control for sex, education, race and marital status the estimate is 0.0832 with a standard deviation of 0.0054 .

Although I don't know $\operatorname{Pr}\left(N_{t}=1 \mid C_{t}=1\right)=E\left(N_{t} \mid C_{t}=1\right)$ and $\operatorname{Pr}\left(N_{t}=1 \mid C_{t}=\right.$ $0)=E\left(N_{t} \mid C_{t}=0\right)$ for the years after 1994, I can estimate these probabilities using data from the 1992 and 1994 waves assuming that the probability of contacting SSA and the effects from contacting SSA wouldn't have changed over time. Given these assumptions the overstatement of the effect of the Statement for workers who

\footnotetext{
${ }^{13}$ The actual benefits are computed using the administrative records that are linked to the HRS. Using actual benefits reported in later waves gives very similar results.

${ }^{14}$ The dependent variable is equal to one when workers respond that they "don't know" their Social Security benefits. The very few workers who refuse to respond are not included in the regressions.
} 
didn't contact SSA is approximately equal to 2.4 percentage points (30 percent) when using data up to 1996: $\left[E\left(N_{t-2} \mid C_{t-2}=1\right)-E\left(N_{t-2} \mid C_{t-2}=0\right)\right] P\left(C_{t}=\right.$ $\left.1 \mid C_{t-2}=0\right)=0.30 \times 0.08$.

A similar conclusion is reached when, in order to use the whole data, I estimate a regression model with known probabilities of misclassification of the variable $C$. Defining $C^{*}$ as the true event and $C$ as the misclassified one, the true effect of the Statement for group $x$ is proportional to the misclassified one

$$
\begin{array}{r}
{[E(N \mid C=0, T=x)-E(N \mid C=1, T=x)]} \\
=\left[E\left(N \mid C^{*}=0, T=x\right)-E\left(N \mid C^{*}=1, T=x\right)\right] \\
\times \operatorname{Pr}\left(C^{*}=0 \mid C=0\right), \quad x=0,1
\end{array}
$$

where the factor of proportionality is the probability of correctly classifying $1-C$. Controlling for other $X$ 's, it can be shown that the estimated true effect of the Statement is equal to $\widehat{\beta}_{11}$ in the following linear model 15

$$
\begin{aligned}
N= & \beta_{00}+\beta_{01}(1-C) \operatorname{Pr}\left(C^{*}=0 \mid C=0, X\right)+\beta_{10} T_{1} \\
& +\beta_{11}(1-C) \operatorname{Pr}\left(C^{*}=0 \mid C=0, X\right) T_{1}+X^{\prime} \gamma+\epsilon .
\end{aligned}
$$

This is the specification used from column (4) on, where I interact the probability of not having contacted the SSA and the post-Statement variable. This way I measure the treatment effect on the treated, and indeed the entire effect of the Statement is concentrated among those who never contacted the SSA (60 percent of the sample). Column (4) shows that not having contacted the SSA increases the initial probability of not reporting an estimate in the pre-Statement period by 26 percentage points, a very large effect. Notice also that this additional variable captures half of the effect of being black and reduces the differences due to the level of education. This means that blacks and workers with low levels of education are not only less likely to contact SSA in order to get informed, but are also less likely to get informed using other channels.

For those that don't contact the SSA, the Statement reduces the probability of not reporting an estimate by 11 percentage points, approximately one third of the initial difference. Columns (5) and (6) show that controlling for age and year fixed effects and for health and wealth does not change the estimated effects of

\footnotetext{
${ }^{15}$ In order to control for the variation that is due to the first step, I can either use a modified version of Murphy and Topel (1985)'s two-step estimator that accounts for the panel structure (dependence over time), or I can simply bootstrap clusters of individuals and than run the first and second step. Since doing so has negligible effects on the standard errors (mainly due to the precision of the estimate of $\left.\operatorname{Pr}\left(C_{t}=1 \mid C_{t-2}=0, X\right)\right)$, the analysis is carried out conditional on the estimate from the first stage.
} 
the Statement 16

The effect on knowledge could be different at different ages, and thus could have very different effects on retirement behavior. The effect of the Statement might be concentrated at younger ages, just anticipating the information, with small potential of changing retirement behavior. In order to capture how the Statement can differently affect different age groups, the first column in Table 4 reports for each age the fraction of workers who have contacted the SSA. Since almost all workers claim by age 65, the table is truncated at age 64 . Most workers contact the SSA when they are close to retirement. Around 30 percent call in their 50 s, while an additional 20 percent call when they approach the early retirement age.

In the remaining columns of Table 4, I analyze how at different ages the probability of reporting a benefit estimate changes upon receiving a Statement 17 The sample is split into those who did and those who didn't contact the SSA (using again a model with misclassification errors and known probabilities of misclassification). Among those who contacted the SSA there is a clear reduction in the probability of not reporting an estimate as I approach the early retirement age. There is no such pattern for those who didn't contact the SSA in the pre-Statement period. In the post-Statement period, there is a clear improvement around the early retirement age. The effect of the introduction of the Statement can be seen by looking at the Pre-Post columns. There are 2 Pre - Post columns, the first does not control for other regressors (gender, education, experience, and veteran status), the other does. Among those who contacted the SSA the differences are not significantly different from zero. On the other hand, among workers who didn't contact the SSA, the Statement reduced the fraction by around 10 percentage points up to age 58 and 20 percentage points afterwards. In relative terms, the effect around the early retirement age is to reduce the fraction of workers that are unable to provide a benefit estimate by almost one half 18 After age 58 the differences are significant at the 1 percent level (except at age 64 where the sample size is also very small).

Next I analyze whether the Statement improves the estimates of those who provide an estimate. Figure1 shows the density of the forecast error (the difference between the expected and the actual benefits) for those workers who did and didn't

\footnotetext{
${ }^{16}$ The results are not different when, disregarding an endogeneity problem, I also control for the time left from the expected retirement date (results available upon request).

${ }^{17}$ I performed a similar analysis using instead of age the expected number of remaining years from retirement, and the results were very similar.

${ }^{18}$ The effect at even earlier ages are small. Workers in their 40 s and early 50 s are only 3-6 percentage points more likely to provide an estimate as a consequence of receiving the Statement (results available upon request). This cast some doubt on the utility of sending the Statements to young workers that seem to show little interest for them.
} 
contact the SSA 1920 Errors seem to be approximately distributed symmetrically around zero, which suggests that, on average, there is no prediction bias. In the pre-Statement period (solid line) the variability of the errors for workers who didn't contact the SSA is much larger than for those who contacted the SSA; this difference seems to disappear once the Statement is introduced (dashed line). As before, this change in the distribution of the error term is likely to be upward biased by the fact that some workers would have contacted the SSA in the absence of the Statement. Substituting workers who didn't contact the SSA with workers who contacted the SSA with probability equal to the probability of contacting the SSA over a two-year period 21 and plotting the corresponding pre-Statement density allow us to judge the expected improvement that is not attributable to the Statement (dotted line).

In Table 5, I test whether the distributional differences in Figure 1 are significant. For workers who didn't contact the SSA I use the pre-Statement density that controls for the expected improvements (dashed line). Most of the improvement seems to lie within one standard deviation from the mean, which is why I test if the ratio of the pre-Statement to the post-Statement variance is larger than one, truncating the error at $\pm \$ 1000, \pm \$ 500$, and $\pm \$ 30022$ The p-value of this one-sided test for those who didn't contact the SSA is zero for the $\$ 1000$ truncation and close to zero as I concentrate the analysis to errors that are closer to the median. For those who contacted the SSA I can reject the hypothesis that the variance decreased after the introduction of the Statement. It is worth noting that although the variance of the forecast error decreased for those who were previously uninformed, similarly to what I observed before for the probability of reporting an estimate, their post Statement errors are still larger compared to the other group.

The above analysis suggests that thanks to the Statement some workers became more knowledgeable about their Social Security benefits. The workers for whom I observe an improvement didn't contact the SSA before. The profile of those workers is consistent with the idea that information is costly. Controlling for various factors reduces the difference due to educational and gender by about one third. While the remaining differences could be due to different preferences over leisure,

\footnotetext{
${ }^{19}$ Benefits are expressed in 2003 dollars using the CPI. I take into account that actual Social Security benefits refer to the year before the interview. Results using the relative forecast error are similar.

${ }^{20}$ Note that to highlight the distributional differences I truncated the distribution of the error at $\pm \$ 1000$ (3 percent of the sample).

${ }^{21}$ These graphs use only information up to 1996 and therefore the probability is simply equal to 8 percent.

${ }^{22}$ The reason to use truncated values is that variances are highly sensitive to outliers. Without truncation the variance of the error is even larger in the pre-Statement period. In the HRS, respondents can report weekly, monthly, biyearly, and yearly values. The big discrepancies seem to be due to the few observations with measurement errors in the variable that reports this "frequency" variable.
} 
another possible reason might be financial illiteracy 23 Lusardi and Mitchell (2006) show that black workers and workers with low levels of education are significantly less likely to respond correctly to simple questions about compound interest, inflation, and portfolio management.

The important lesson is that the free availability of information is not sufficient to get informed. Obtaining information seems to be costly and might prevent workers who think that information is of little value to become knowledgeable. Stimulating workers by directly providing them with information reduces that cost and has the predictable effect of improving workers' knowledge. In the next section, I test whether and how the new information affects workers' retirement decisions.

\section{The Effect of the Statement on Retirement and Social Security Benefit Claiming Behav- ior}

The additional information provided by the Statement can influence workers' behavior in many ways. There may be a "surprise" effect: workers who overestimated their expected Social Security benefits should react by working and saving more, while those who underestimated their benefits should do the opposite. Although changes in labor supply may also happen at the intensive level (hours), I focus on changes at the extensive level (participation). Since forecast errors are approximately symmetrically distributed around zero, these changes may go in both directions. Also, as over time the age at which workers received their first Statement decreases, I should expect these "surprise" effects to weaken. In addition, even if the decision of becoming informed is the sole product of a maximization process with costly information, at the margin the Statement should strengthen the link between Social Security incentives and retirement.

Because of liquidity constraints and the earnings test (ET), the retirement decision is strongly related to the claiming decision. According to the HRS data, half of the time the monthly self-reported retirement date and the monthly selfreported claiming date are not more than 12 months apart from each other. When the difference between the two dates is larger than one year, the difference is mainly due to early retirement. Among those who retire at or after age 62, 75 percent claim and retire within a year.

Before moving to the analysis, let me mention the other major Social Security reforms that happen around the time of the introduction of the Statement and might have changed workers' retirement and claiming behavior. One important

\footnotetext{
${ }^{23}$ Another explanation may be that some workers prefer to procrastinate O'Donoghue and Rabin (1999).
} 
reform is the 2000 earnings test removal for workers above the normal retirement age (usually 65). Earnings of Social Security beneficiaries above the earnings test threshold, up to their benefit amount, are taxed away at a 50 percent rate between age 62 and 65, and, before 2000, at a 33 percent rate between 65 and 69 . Although the earnings tax is only that high for myopic workers, the reason being that benefits that are taxed away increase future benefits at an almost actuarially fair rate through the so-called recomputation, workers are sensitive to the tax. The removal had the effect of increasing the fraction of workers who claim their Social Security benefits at the normal retirement age, the age at which the tax was removed (Mastrobuoni, 2006).

The other two reforms changed the benefit formula. In response to an earlier "crisis" in Social Security financing two decades ago, the US Congress implemented both a reduction in the Normal Retirement Age (NRA) of two months per year for cohorts born in 1938 and afterward, and, staring in 1986, an increase in the delayed retirement credit (DRC) 24 that is the actuarial adjustment to the benefits when retirement is postponed beyond the normal retirement age. The DRC has been increased by half a percent every other year from its original 3 percent. It is going to reach its final value of 8 percent for workers born in 1943 or later.

\subsection{The Effect of the Statement on Workers' Expected Claiming Behavior}

Before looking at the actual retirement and claiming behavior, I analyze whether at the time Statements are sent out workers change their retirement plans 25 I would expect workers to be more likely to change their expectations when they receive their first Statement, and less likely afterwards. Using the panel structure of the HRS, I estimate the effect of the Statement on the probability that the expected claiming age stays constant 26 All regressions include age fixed effects, levels of education, marital status and race. I also control for a linear time trend and for the 2000 earnings test removal. In Table 6 I report the marginal effects of the Statement on the probability of keeping the same expected claiming age. The first column allows for just a one-time effect, which is small and not significantly different from zero. Column (2) shows that those who did not contact the SSA are significantly more likely to change their expected claiming age.27 The estimates in both of these columns are contaminated by the fact that the first Statement should

\footnotetext{
${ }^{24}$ See Mastrobuoni (n.d.).

${ }^{25}$ Chan and Stevens (2004) use these data to estimate a model of expected retirement.

${ }^{26}$ I tried to replicate the same analysis with respect to the expected retirement age, though only a few workers are asked about their expected retirement date, and so the sample size was too small to estimate any effect.

${ }^{27}$ I control for the fact that contacting SSA is endogenous by estimating the model using the probabilities of misclassification in same manner as when I dealt with the probability of providing a benefit estimate.
} 
have the opposite effect than subsequent Statements. In column (3), I include an indicator variable equal to one when the person already received a Statement in the previous wave. The coefficient has a positive sign, meaning that receiving a second Statement increases the probability of maintaining the same expected age, though the effect is not significant. In column (4), I interact both Statement effects with the "No SSA contact" dummy. Both, the effect of the first Statement and the effect of additional Statements is not significantly different for the two groups.

Workers may not pay attention to the first Statement they receive, so there is a potential measurement error problem. This may explain why the effects are generally small and not significant. This measurement error problem is less salient when analyzing actual claiming. In the next section I analyze detailed data on claiming patterns around the introduction of the Statement.

\subsection{Social Security Claiming Patterns}

Most workers claim at the "Early" and the "Normal" retirement (Lumsdaine et al., 1996). One possible explanation is that workers use that age as a focal point. Another surprising fact that cannot be easily explained by the incentives is that the grand majority of workers claim their benefits immediately after their birthdays. If the Statement improves workers' understanding of the Social Security incentives they should become less likely to claim at these particular ages.

On the other hand, the Statement emphasizes the benefits the workers would get at 62 , at the NRA, and at age 70 , the age after which no more actuarial adjustments are made. Workers might thus tend to focus on those ages even more. Figure 2 to 4 show the probability of retiring within a month of the 62 nd birthday, within a month of the Normal Retirement Age, and within a month of the 70th birthday, both, before and after the introduction of the Social Security Statement based on SSA's Master Beneficiary Records (1 percent of all retirees). All the Figures show that there is a tendency for people to claim the benefits in January, but there is no discontinuity in the claiming patterns when the Statements are introduced. The only remarkable change is the increase in the probability of claiming at the NRA following the elimination of the ET for cohorts born after 1935.

It might still be that workers changed their claiming behavior due to the Statements, but that these changes cancel out in the aggregate due to the symmetry around zero of the benefits' forecast errors. The next step is to evaluate the impact that the Statement had on retirement using individual data.

\subsection{Social Security Incentives}

Postponing retirement by one year can generate considerable changes in SSW (the SSW accrual). Positive accruals generate an incentive to work. Figure 5 shows 
that there are two pronounced retirement rate spikes: at the early retirement age (ERA) and at the normal retirement age (NRA). Around 17 percent of people retire at the age of 62, and among those who do not claim before age 65, 20 percent retire at age 65. Some factors can partially explain this clustering: large disutility from work and/or a large discount rate (ERA spike) and discontinuities in the actuarial adjustment rates (NRA spike) (Lumsdaine et al., 1996, Panis et al., 2002). Phelan and Rust (1997) attribute part of the 62-spike to liquidity constraints and part of the 65-spike to lock-in effects due to Medicare when workers lack alternative health insurance in retirement 28

In order to analyze whether the Statement makes workers more responsive to Social Security incentives I first need to compute these incentives. Thus I need to forecast earnings and compute future benefits as a function of the retirement age. Below I briefly review the main provisions of the benefit formula and the assumptions needed to compute the Social Security Wealth.

I compute the Social Security benefits $B_{t}(a)$ for each retirement age using the same assumptions used by the SSA to provide an estimate in the Statement. The Statement assumes that if the worker doesn't retire he/she is likely to earn the same amount he/she earned last year (or the year before if last year's earnings are zero). In other words, real earnings are assumed to follow a random walk, so that the previous year's earnings are the best predictor for future earnings. This assumption is not very different from Coile and Gruber (2001), who assume that real earnings are expected to grow by one percent. Every year, benefits are then computed as a function of age (from age 55 to 70) and as a function of the retirement age (from the worker's actual age to age 70 ). The benefit rules are held constant, and it is assumed that promised benefits are going to be paid. Workers who retire before age 62 are assumed to claim at age 62 .

I do not model the spouse's retirement decision, and I assume that the spouse claims at the earliest possible age 29 The Statement explains what spouse benefits, and survivors benefits are, but it doesn't provide an estimate of these benefits. I estimate retirement models with and without taking into account these additional benefits and the results are generally very similar. I define a spouse as "independent" when his/her own benefits at age 62 are larger than 50 percent of her spouse's benefits at age 62 .

\footnotetext{
${ }^{28}$ Their explanation is at odds, however, with the evidence from the 1961 change in the early retirement age from 65 to 62 . While the ERA has changed suddenly, the spike in retirement has moved very slowly (over 30 years, Burtless (1999)). Based on this evidence, Axtell and Epstein (1999) suggest that spikes may not be entirely the product of rational decision making but resemble some herd behavior. Additional support for a behavioral explanation of the spikes is provided by the recent increase in the NRA suggested by the 1983 Greenspan Commission. Mastrobuoni (2006) shows that the entire 65-spike at which the workers claim their Social Security benefits moved together with NRA. This contradicts the Medicare explanation as the Medicare eligibility at age 65 remained unchanged. The Social Security Statement contains the advice that, "even if you do not retire at age 65, be sure to contact Social Security three months before your 65th birthday to enroll in Medicare."

${ }^{29}$ Most of the times it is age 62 , which also represents the median claiming age.
} 
Benefits are a function of the weighted average of the highest 35 years of average wage-indexed earnings, called the AIME. Since workers tend to have lower earnings at the beginning of their career than at the end working an additional year normally increases future benefits even at age 62 , which generates an additional incentive to work. However, Table[7]shows that between age 55 and 61 the increase in Social Security benefits is modest. Its median ranges between 1 percent and 2 percent. Starting at age 62 instead, the increase is substantial. An 8 percent actuarial adjustment has to be added to the median 1 percent increase that is due to current earnings. Looking at benefits only doesn't take into account that working an additional year means that benefits are not collected in that year, and that Social Security taxes are paid on the additional earnings up to the maximum taxable threshold. This is clearly stated in the Statement but the Statement does not provide workers with estimates of this intertemporal trade-off. This is why later in the regression I use the simple increase in the benefits as the most naive form of Social Security incentives.

More forward-looking incentives depend on the number of years that workers, and possibly their spouses, expect to collect benefits. It also depends on their discount rate. The SSW is a function of time $t$ and retirement age $a$ :

$$
S S W_{t}(a)=P D V_{t}(B(a))=\sum_{t=s}^{T} \beta^{t-s} p_{t}(s) B_{t}(a)
$$

Following the literature I use a real discount rate of 3 percent $(\beta=1.03) 30 B_{t}(a)$ 's are expressed in 2003 dollars using the CPI, and the conditional probabilities of survival, $p_{t}(s)$, are based on the SSA's cohort-specific life tables 31 In a second set of regressions, that are available upon request because the results are very similar, I correct the probabilities of survival for the ratio between the subjective probability of surviving age 75 and the same probability taken from the life tables 32

Since I lack precise information on dependent children, the benefits include dependent benefits and survivors' benefits, related only to the spouse. In that case $p_{t}(s)$ is a column vector where the entries are: the probability that only the

\footnotetext{
${ }^{30}$ There is some evidence that discount rates may actually be larger than 3 percent (Samwick, 1998). On the other hand, Blinder et al. (1981) argue that in the absence of borrowing constraints it is more appropriate to use a real interest rate instead, which can be assumed to be very low (they use 1 percent). I follow the mainstream literature and use a 3 percent discount rate, though the reduced form model estimated controlling for age seems to be robust to the use of different discount rates. The reason is that controlling for age the effect of the accrual is mostly identified by the accrual's cross-sectional variation within age, while the use of different discount rates generates mainly large differences across age.

${ }^{31}$ The life tables are prepared by the Office of the Chief Actuary in the Social Security Administration. Projected death rates and life tables are based on Alternative II forecasts for the 1998 Trustees report (taken from the Berkeley Mortality Database). To compute total Social Security benefits (including spouse's benefits and survivors' benefits) when using the tables I'm implicitly assuming that the couple's individual mortalities are independent.

${ }^{32}$ The RAND version of the HRS contains this variable, called "rliv75r."
} 
worker survives, the probability that only his wife survives, and the probability that both survive. $B_{t}(a)$ is a row vector containing the worker's own benefits, the survivors's benefits, and the sum of the worker's own benefits and the dependent spouse's benefits.

The Social Security accrual is the expected gain in SSW from waiting an additional year before retiring and claiming Social Security benefits 33

$$
A C C_{t}(a)=S S W_{t}(a+1)-S S W_{t}(a)
$$

while the peak-value (PV) Coile and Gruber (2001) is the difference between the maximum SSW and the current SSW,

$$
P V_{t}(a)=\max _{x} S S W_{t}(x)-S S W_{t}(a)
$$

Retirement decisions based on PV's and ACC's differ whenever ACC's are not monotonic relative to the retirement age. I also compute relative incentives, $A C C_{t}(a) / S S W_{t}(a)$, and $P V_{t}(a) / S S W_{t}(a)$. For this reason the sample is restricted to workers with positive Social Security Wealth. If workers are below age 62 and retire the Social Security Wealth is equal to the Social Security Wealth they will get at age 62 discounted to their age.

The remaining columns of Table 7 show accruals with and without dependent benefits and with and without taking Social Security payroll taxes into account. I compute the accrual net of Social Security taxes, $t W_{t}(a)$, assuming, like in Diamond and Gruber (1998), that workers bear the entire payroll tax, $t$ (12.4 percent since 1990). Since I do not observe income I do not attempt to try to simulate income taxes, though in the regressions the different tax treatment of Social Security benefits should in part be absorbed by the coefficient on earnings 34

Table 7 shows that there is heterogeneity in accruals (in thousands) over age and within age from postponing retirement. Part of it is due to the eligibility to different types of benefits (i.e., dependent spouse's benefits). Differences in earnings histories, current earnings, and Social Security rules account for the rest. Individuals, especially men, who evaluate the future streams of Social Security benefits taking only their own benefits into consideration (either because they have no dependents, or because their spouses are better off by claiming their own benefits) generally face negative or null increases in SSW from additional work. The summary statistics of all the different incentives used are shown in Table 8 .

\footnotetext{
${ }^{33}$ I assume that workers claim and retire in the same year.

${ }^{34}$ If a beneficiary files a federal tax return as "an individual," ("a couple") and the combined income is between $\$ 25,000$ and $\$ 34,000(\$ 32,000$ and $\$ 44,000)$ in 2004 , he or she pays taxes on 50 percent of the Social Security benefits. If the combined income is more than $\$ 34,000(\$ 44,000)$, up to 85 percent of the Social Security benefits are subject to income tax.
} 


\subsection{The effect of the Statement on Retirement Behavior}

\subsubsection{A Measurement Error Model of Optimal Retirement Behavior}

Reduced form models of retirement have been used extensively in the retirement literature. Coile and Gruber (2002) estimate a probit reduced form model of retirement that incorporates forward-looking Social Security incentives. Their concept is based on the Option Value model of Stock and Wise (1990), a model that resembles a dynamic programming model although it introduces some important simplifications. As shown in Table 7, accruals tend to be decreasing with age except between ages 61 and 62 . Since workers may be forward-looking and incorporate future accruals in their retirement decisions Coile and Gruber (2002) and numerous papers that follow their approach use the peak value as the main measure of Social Security incentives. All of these papers use reduced form PV probits, and assume a constant coefficient on the PV 35

I estimate the following linear probability model,

$$
R_{i}=\alpha_{i} A C C_{i}+\beta^{\prime} \tilde{x}_{i}+\epsilon_{i},
$$

where $R$ is equal to one when workers report being retired and zero otherwise, $A C C$ is some sort of Social Security incentive to retie, and $\tilde{x}$ denotes the other regressor, including the earnings $(y)$.36 The model estimates hazard rates as workers are excluded from the sample once they retire.

First, I assume that $\alpha_{i}$ is constant across people and independent of the Statement $T \in\{0,1\}$, while later I allow $\alpha_{i}$ to vary between the pre and the postStatement period:

$$
\alpha_{i}=\alpha_{0}+\alpha_{1} T_{i} .
$$

$\alpha_{0}$ is the effect of the accrual for workers in the pre-Statement period.

Substituting $\alpha_{i}$ into Eq. (6) I get,

$$
R_{i}=\left[\alpha_{0}+\alpha_{1} T_{i}\right] A C C_{i}+\beta^{\prime} \tilde{x}_{i}+\epsilon_{i} .
$$

In this setup, $\alpha_{1}$ represents the difference between the post- and the pre-Statement period in the marginal effect of a unit $(\$ 1,000)$ increase in the accrual on the probability of retirement:

$$
\alpha_{1}=\left.\frac{\partial P(R=1)}{\partial A C C}\right|_{T_{i}=1}-\left.\frac{\partial P(R=1)}{\partial A C C}\right|_{T_{i}=0} .
$$

35 Gustman and Steinmeier (1986), instead, use a more structural approach and assume that workers respond differently to incentives depending on their health, age, and year of birth.

${ }^{36}$ Results based on probit regressions are very similar. 
In order to control for changes in retirement behavior that may be due to the earnings test (ET), I include the average ET tax 37 The higher the average tax, the higher the incentive for a worker to stop working altogether. Table 13 in the Appendix shows the summary statistics for the sample used in the regressions.

All regressions control for the worker's own SSW, the SSW of the spouse, the labor force status of the spouse, age dummies, year, year squared, a postStatement dummy, the level of education, marital status, the own and the spouse's real AIME at age 55, subjective health status dummies, the difference in age relative to the spouse, a no children in the household dummy, veteran status, experience, occupation and industry dummies, and forecasted earnings.

If the researcher observes the true accrual $A C C$, but workers base their decisions on their perceived and sometimes mismeasured accrual $\widehat{A C C}$, the estimated effect will be downward biased (relative to workers' actual intentions). The bias will be higher the higher the variance of measurement error $\operatorname{Var}(\widehat{A C C}-A C C)$. If the Statement allows workers to get a better estimate of their actual Social Security incentives and this better estimate is used to make better retirement decision, the variance would decrease, reducing this "classical-type" measurement error bias. The coefficients in the post-Statement period would thus in absolute value be larger than in the pre-Statement period.

\subsubsection{Results}

Let me first discuss the sample that I use for the regressions. The Statement has been sent out in phases, depending on the age, the fiscal year, and the date of birth of workers. This means that workers born in the same year might have started receiving a Statement in different years. I exploit these discontinuities in the phasing in to select a sample of age in years/year of birth combinations were at least some, but not all individuals in an age in years/year of birth group receive a Statement. Table 9 shows the age/year of birth combinations for the whole HRS linked to the SSA records. The combinations that have at least some but not all workers receiving a Statement are shown in bold. Of this sample 56 percent of individuals receive a Statement. Table 10 shows that controlling for age dummies, year, and year squared almost all other regressors do not on average differ between the pre and the post-Statement period 38 This shows that the treatment and control group have on average similar characteristics.

\footnotetext{
${ }^{37}$ The average $\mathrm{ET} \operatorname{tax}$ is $t_{E T}=\min ($ benefits, (earnings - ETthreshold) $\times$ marginaltax)/benefits. When earnings are below the ET threshold, the marginal tax and the average tax are zero. Special rules apply the first year a worker claims his benefits. Under these rules, a worker can use a monthly test amount. If he/she claims and retires during the year, he/she can get a full Social Security check for any whole month he/she is retired, regardless of his yearly earnings. Since I do not have information on monthly earnings I cannot control for this case, which is why the average tax may be measured with some error.

${ }^{38}$ Around 5 percent of the coefficients should turn out to be significant even if the true effect was zero.
} 
Table 11 shows the results for a constant $\alpha_{i}$. Each column represents a different Social Security incentive. The first column shows the results for the ratio between the earliest benefits the worker would receive retiring in the following year and the earliest benefits would receive retiring immediately. In order to estimate this kind of incentives workers do not have to compute present discounted values. Most of the information needed to compute this incentive is available in the Statement. Increasing the benefits by 1 percentage point decreases the self-reported retirement hazard by 0.537 percentage points. Using the percentage accrual $(A C C / S S W)$ or the percentage accrual net of Social Security contributions gives surprisingly similar results. The coefficient on the accrual tells us that a $\$ 1,000$ increase in the accrual decreases the hazard rate of retiring by 0.337 percentage points, while a similar increase in the peak value decreases the hazard rate of retiring by 0.0757 percentage points 39

The coefficient on the SSW and on the spouse's SSW is not significant. Next, I estimate Eq. 8, allowing $k$ to be different between the pre and the post-Statement period. Table 12 shows only the coefficients related to retirement incentives, this time interacted with the post-Statement dummy. All the coefficient on the interaction are negative, but none is significant. Statistically I cannot rule out that the Statement did not have any impact on workers' retirement behavior. Also the coefficients on the SSW show an absolute increase in the post-Statement period, but again not significantly different from zero.

\section{Conclusions}

There is empirical evidence that a worker's retirement decision responds to forwardlooking retirement incentives. These incentives depend on current and future earnings, and on retirement benefits. Social Security benefits, which represent the most important source of retirement income, are a complicated function lifetime earnings. It is generally assumed that workers know their benefits and are able to compute their retirement incentives.

In order to understand whether this is a reasonable assumption I analyze workers' knowledge. Contacting the SSA represents the single most important channel through which workers learn about their future benefits. I model the probability of contacting the SSA and find evidence that is consistent with the existence of considerable costs of collecting (and processing) information about Social Security benefits: Workers who, for various reasons (health, liquidity, etc.), face simple retirement decisions are less likely to contact the SSA. Additional evidence confirming this result comes from the 1995 introduction of the Social Security Statements. These Statements, which contain an estimate of the worker's benefits if he/she retires at age 62,65 , and 70 , generate an exogenous variation in the cost

\footnotetext{
${ }^{39}$ Panis et al. (2002) estimate a similar regression, though they use a probit and the PV and find a marginal effect of 0.7 percent for the accrual.
} 
of obtaining information. Upon receiving a Statement workers are more likely to be able to provide a benefit estimate and their benefit estimate tends to be more precise. Controlling for the endogeneity of the decision to contact the SSA, I find that the whole improvement is concentrated among those workers who don't contact the SSA.

Then I turn to study how this additional information affects workers' retirement behavior. The introduction of the Statement doesn't improve the overall responsiveness to the retirement incentives. While this might at first seem disappointing given the 36 cents per Statement spent by the SSA, it might either mean that workers are already behaving optimally and that the marginal workers has only very small additional benefits from getting informed, or that the information contained in Statement is not sufficient to improve workers' retirement behavior. This calls for additional research. Moreover, the Statement might still improve the workers' ability to smooth consumption over time. This possibility also needs to be researched. Anyway, one way to improve the information required to make better retirement decisions is to provide forecasted benefits at all 9 possible claiming, instead of just at 62 , at the NRA, and at 70. Moreover, the Statement provides workers with information about their benefits, but it does not calculate a worker's SSW. If this weakens the beneficial effect of the Statement, a possible addition to the Statement could be a table that helps workers calculate their SSW. Since the SSA cannot possibly use individual-specific mortality rates, one easy way to circumvent this problem would be to construct a two-way table that contains "suggested" retirement ages as a function of a worker's expected own and spouse's life-expectancy. 


\section{References}

Axtell, Robert L. and Joshua M. Epstein, "Coordination in Transient Social Networks," in Henry Aaron, ed., Behavioral Dimensions of Retirement Economics, Brookings Institution Press \& Russell Sage Foundation, 1999, pp. 161183.

Bernheim, Douglas B., "Social Security Benefits: An Empirical Study of Expectations and Realizations," Technical Report 2257, National Bureau of Economic Research, Inc May 1987.

_ and Lawrence Levin, "Social Security and Personal Saving: An Analysis of Expectations," American Economic Review, 1989, 79 (2), 97-102.

Blinder, Alan S., Roger H. Gordon, and Donald E. Wise, "Reconsidering the Work Disincentive Effects of Social Security," National Tax Journal, June 1981, 33 (4), 431-442.

Burtless, Gary, "An Economic View of Retirement," in Henry Aaron, ed., Behavioral Dimensions of Retirement Economics, Brookings Institution Press \& Russell Sage Foundation, 1999, pp. 7-42.

Chan, Sewin and Ann Huff Stevens, "Do Changes in Pension Incentives Affect Retirement? A Longitudinal Study of Subjective Retirement Expectations," Journal of Public Economics, 2004, 88 (7-8), 1307-1333.

_ and _, "What You Don't Know Can’t Help You: Pension Knowledge and Retirement Decision-Making," The Review of Economics and Statistics, 042008 , 90 (2), 253-266.

Coile, Courtney and Jonathan Gruber, "Social Security And Retirement," Working Papers, Center for Retirement Research at Boston College 2000-11, Center for Retirement Research October 2002.

Coile, Courtney C. and Jonathan Gruber, "Social Security Incentives for Retirement," in David Wise, ed., Themes in the Economics of Aging, University of Chigaco Press, 2001, chapter 10, pp. 311-341.

_ and _, "Future Social Security Entitlements and the Retirement Decision," Review of Economics and Statistics, May 2007, 89 (2), 232-246.

Diamond, Peter A. and Jonathan Gruber, "Social Security and Retirement in the U.S.," in Jonathan Gruber and David A. Wide, eds., Themes in the Economics of Aging, Chicago: University of Chicago Press, 1998.

Gustman, Alan L. and Thomas L. Steinmeier, "A Structural Retirement Model of Retirement," Econometrica, May 1986, 54 (3), 555-584. 
_ and _ , "Imperfect Knowledge, Retirement and Saving," Technical Report 8406, National Bureau of Economic Research, Inc August 2001.

Helman, Ruth and Variny Paladino, "Will Americans Ever Become Savers?," Issue Brief 268, Employee Benefit Research Institute April 2004.

Jackson, Howell E., "Accounting for Social Security Benefits," in "Behavioral Public Finance," Russell Sage Foundation, 2005.

Krueger, Alan and Bruce Meyer, "Labor Supply Effects of Social Insurance," in "Handbook of Public Economics," Vol. 4, Amsterdam: North-Holland, 2002.

Liebman, Jeffrey B., Erzo F.P. Luttmer, and David G. Seif, "Labor Supply Responses to Marginal Social Security Benefits: Evidence from Discontinuities," Journal of Public Economics, forthcoming, December.

Lumsdaine, Robin, James H. Stock, and David A. Wise, "Why are Retirement Rates so High at Age 65?," in David A. Wise, ed., Advances in the Economics of Aging, University of Chicago Press, 1996, pp. 61-82.

Lusardi, Annamaria and Olivia S. Mitchell, "Financial Literacy and Planning: Implications for Retirement Wellbeing," DNB Working Papers 078, Netherlands Central Bank, Research Department January 2006. available at http://ideas.repec.org/p/dnb/dnbwpp/078.html.

_ and _, "Baby Boomer retirement security: The roles of planning, financial literacy, and housing wealth," Journal of Monetary Economics, January 2007, 54 (1), 205-224.

Mastrobuoni, Giovanni, "The Social Security Earnings Test Removal. Money Saved or Money Spent by the Trust Fund?," CEPS Working Paper 133, Princeton University August 2006.

_ , "Labor Supply Effects of the Recent Social Security Benefit Cuts: Empirical Estimates Using Cohort Discontinuities," Journal of Public Economics, forthcoming.

Murphy, Kevin M and Robert $\mathbf{H}$ Topel, "Estimation and Inference in TwoStep Econometric Models," Journal of Business 83 Economic Statistics, 1985, 3 (4), 370-79.

O'Donoghue, Ted and Matthew Rabin, "Procrastination in Preparing for Retirement," in Henry Aaron, ed., Behavioral Dimensions of Retirement Economics, Brookings Institution Press \& Russell Sage Foundation, 1999, pp. 125156. 
Panis, Constantijn, Michael Hurd, David Loughran, Julie Zissimopoulos, Steven Haider, and Patricia St.Clair, "The Effects of Changing Social Security Administration's Early Entitlement Age and the Normal Retirement Age," report for the SSA, RAND 2002.

Phelan, Christopher and John Rust, "How Social Security and Medicare Affect Retirement Behavior in a World of Incomplete Markets," Econometrica, July 1997, 65 (4), 781-831.

Samwick, Andrew A., "New Evidence on Pensions, Social Security, and the Timing of Retirement," Working Paper 6534, NBER 1998.

SSAB, "The Social Security Statement, How it Can Be Improved," Technical Report, Social Security Advisory Board 2009.

Stock, James H. and David A. Wise, "Pensions, the Option Value of Work and Retirement," Econometrica, 1990, Vol.58 (5), 1151-1180. 

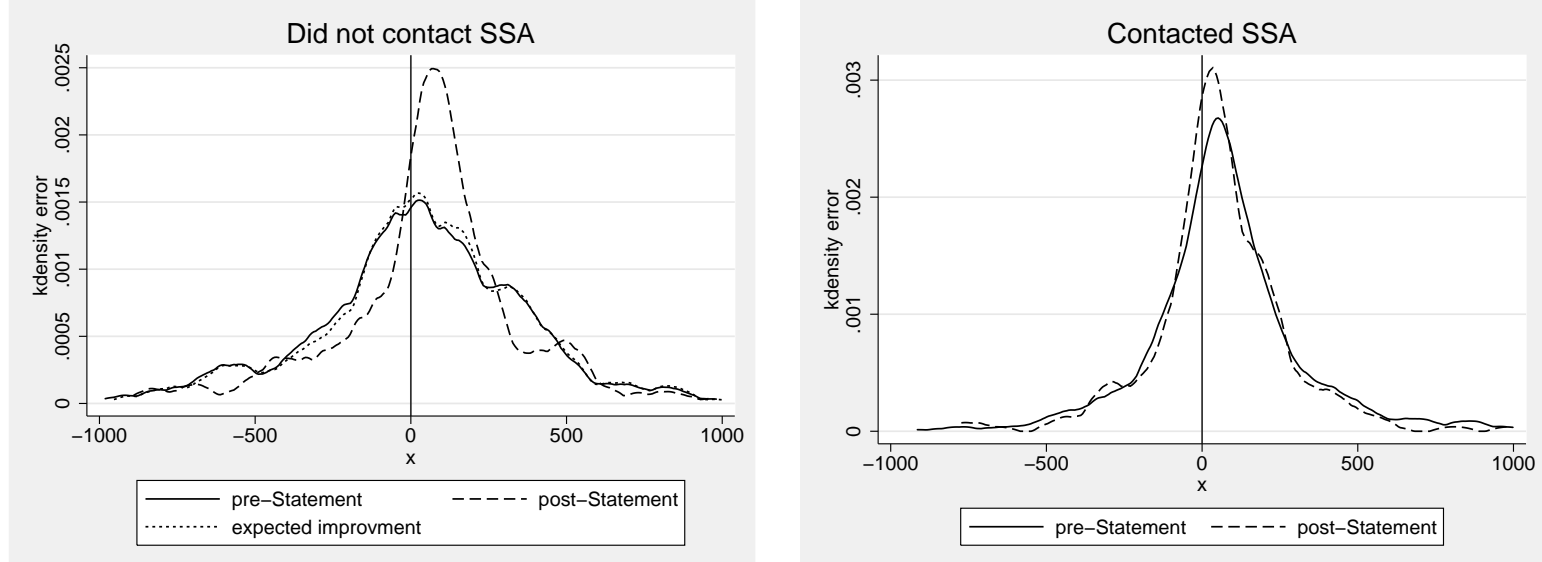

Figure 1: Monthly forecast error. Epanechnikov kernel estimate using a $\$ 35$ bandwidth. Sample: HRS 1992-1996, age 55-65. 


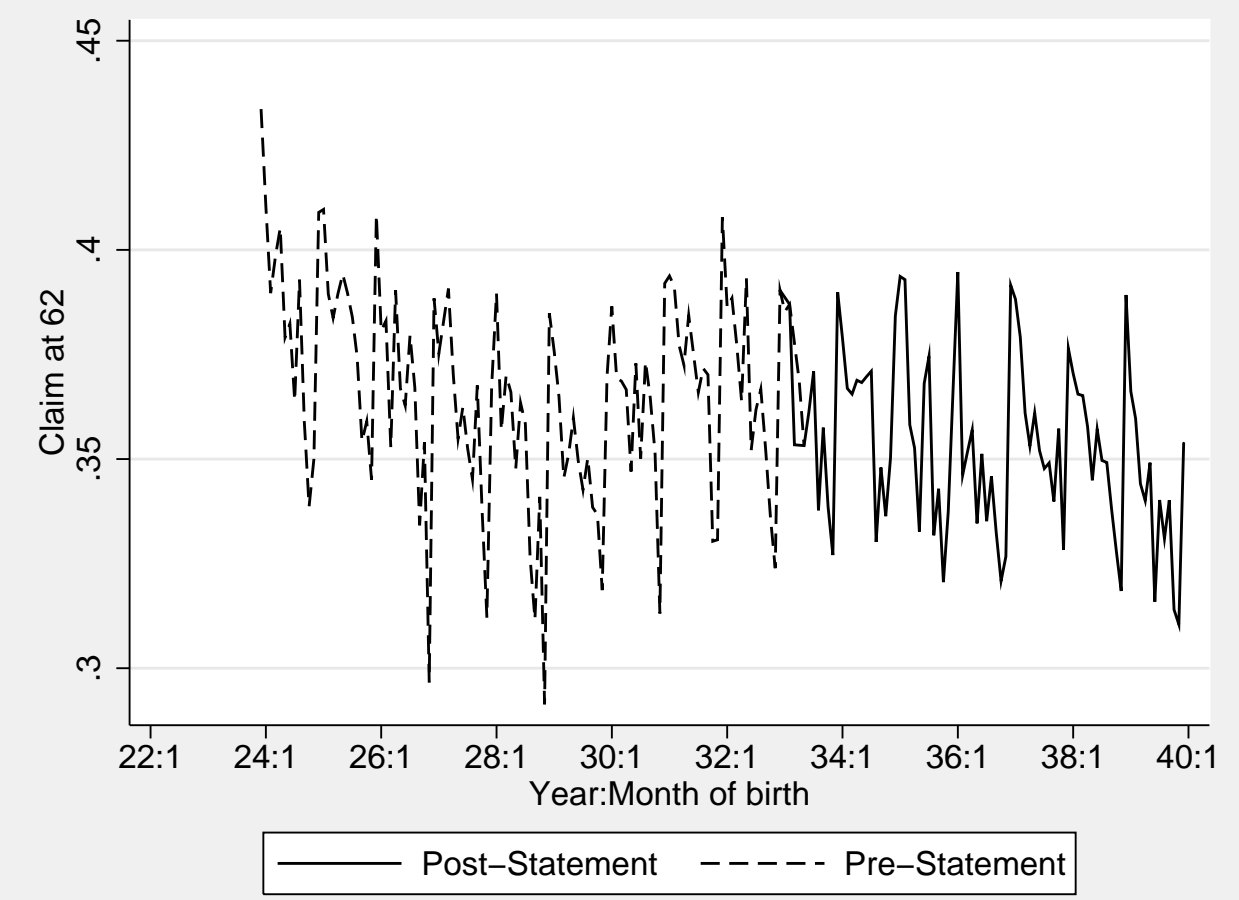

Figure 2: Probability of Retiring at Age 62

Notes: Probability of retiring within a month of the 62 nd birthday. Source: Master Beneficiary records. 


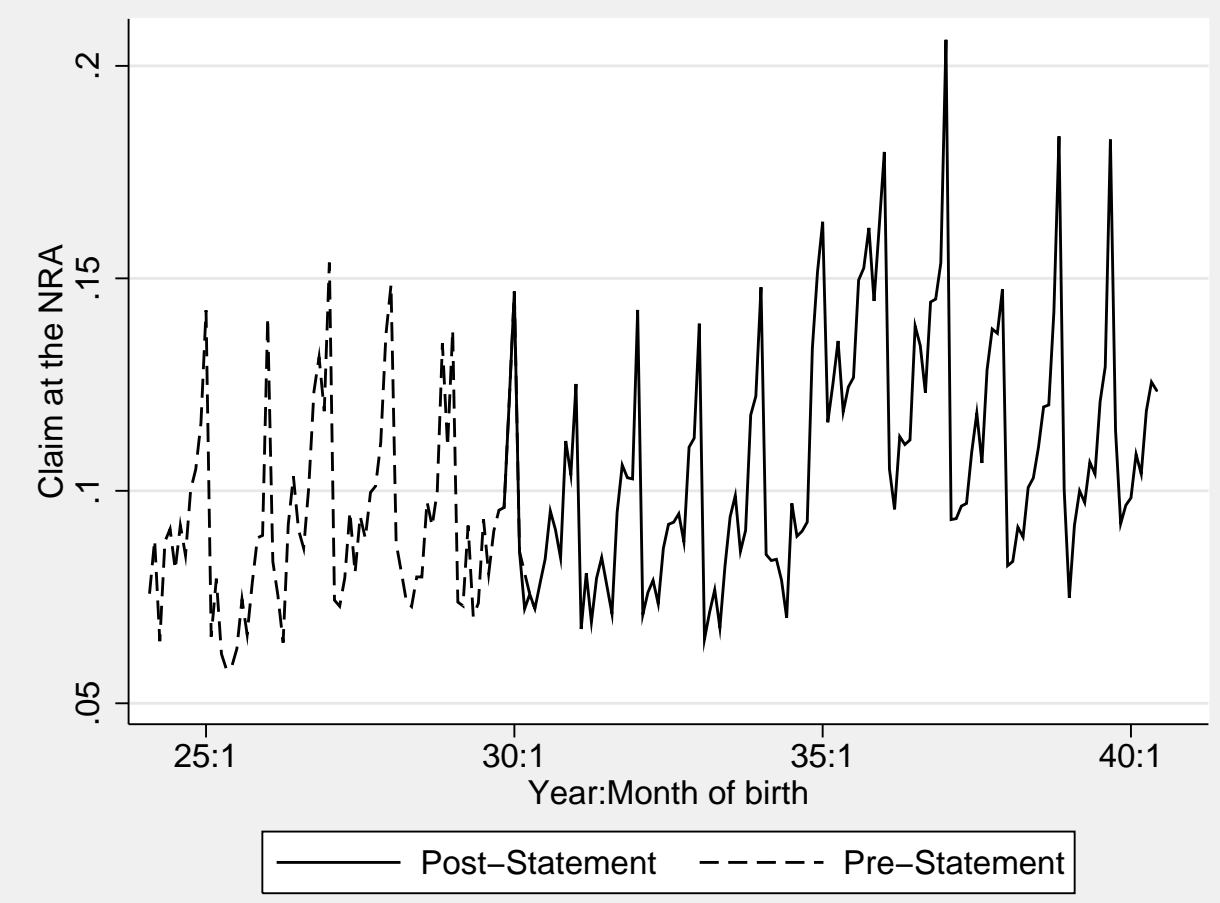

Figure 3: Probability of Retiring at the NRA

Notes: Probability of retiring within a month of the NRA. Source: Master Beneficiary records. 


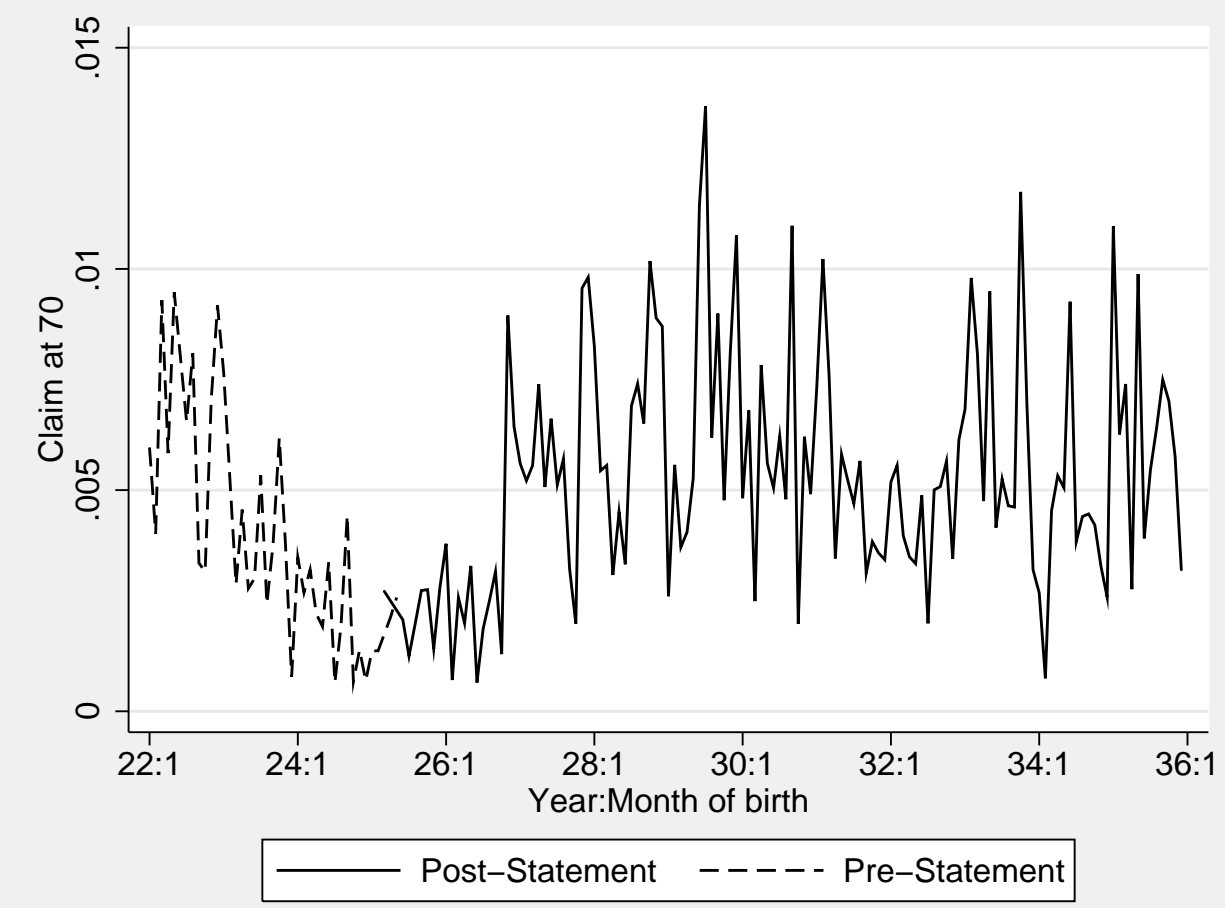

Figure 4: Probability of Retiring at Age 70

Notes: Probability of retiring within a month of the 70th birthday. Source: Master Beneficiary records. 


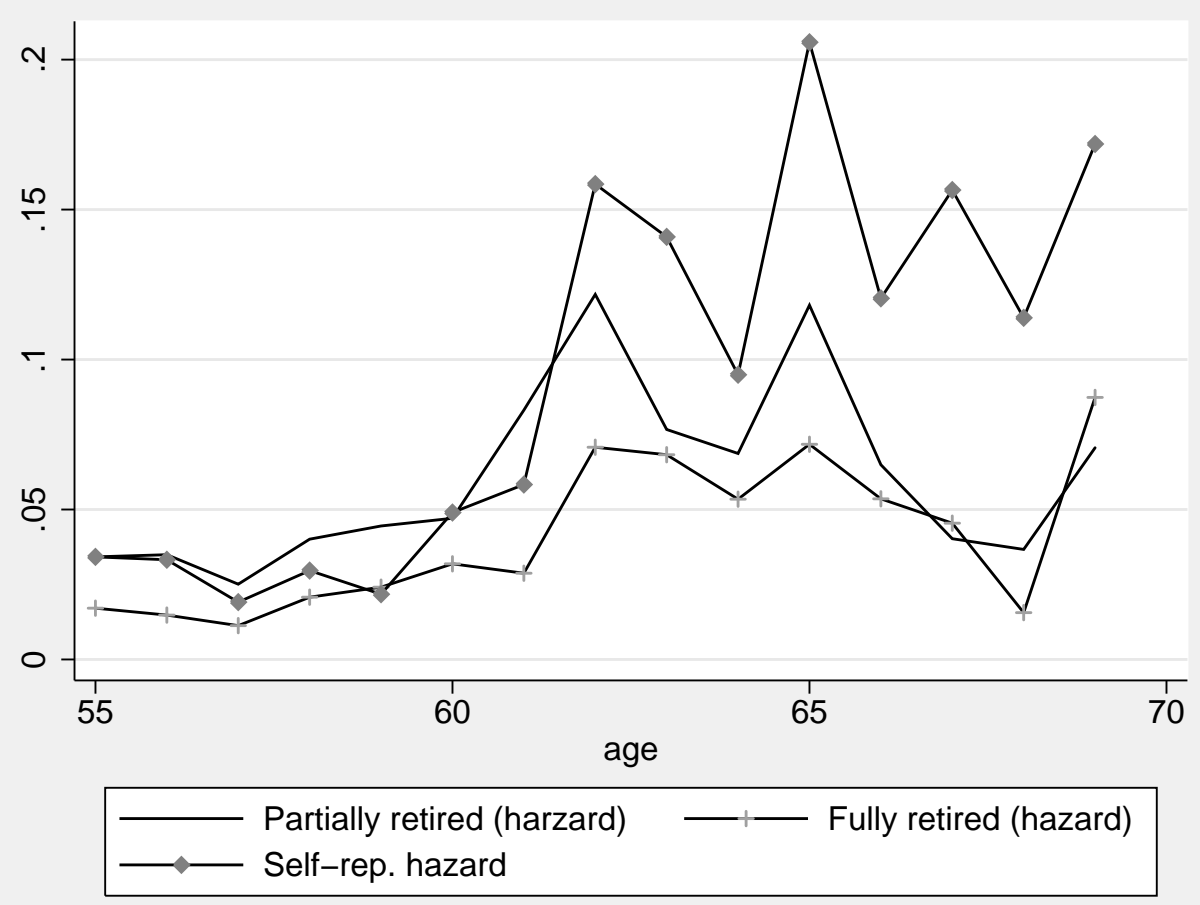

Figure 5: Retirement hazards

Notes: Partial retirement represents a drop of earnings of at least 50 percent. For full retirement earnings need to drop to zero. Source: HRS merged with administrative records. 
Table 1: The Phasing in of the Social Security Statement: Fraction of Workers Receiving a Statement

\begin{tabular}{ccccccc}
\hline & 1994 & 1995 & 1996 & 1997 & 1998 & 1999 \\
46 & 0 & 0 & 0 & 0.06 & 0.32 & \\
47 & 0 & 0 & 0 & 0.10 & 0.85 & 1 \\
48 & 0 & 0 & 0.00 & 0.10 & 0.85 & 1 \\
49 & 0 & 0 & 0.00 & 0.10 & 0.85 & 1 \\
50 & 0 & 0 & 0.00 & 0.10 & 0.85 & 1 \\
51 & 0 & 0 & 0.00 & 0.10 & 0.85 & 1 \\
52 & 0 & 0 & 0.04 & 0.21 & 0.85 & 1 \\
53 & 0 & 0.00 & 0.08 & 0.85 & 1 & 1 \\
54 & 0 & 0.00 & 0.08 & 0.85 & 1 & 1 \\
55 & 0 & 0.00 & 0.08 & 0.85 & 1 & 1 \\
56 & 0 & 0.00 & 0.08 & 0.85 & 1 & 1 \\
57 & 0 & 0.10 & 0.22 & 0.85 & 1 & 1 \\
58 & 0 & 0.15 & 0.89 & 1 & 1 & 1 \\
59 & 0 & 0.19 & 0.89 & 1 & 1 & 1 \\
60 & 0 & 0.75 & 1 & 1 & 1 & 1 \\
61 & 0 & 0.75 & 1 & 1 & 1 & 1 \\
62 & 0 & 0.75 & 1 & 1 & 1 & 1 \\
63 & 0 & 0.75 & 1 & 1 & 1 & 1 \\
64 & 0 & 0.75 & 1 & 1 & 1 & 1 \\
\hline
\end{tabular}

Source: Internal documents of the Social Security Administration. 
Table 2: Linear probability model of contacting the SSA.

\begin{tabular}{|c|c|c|c|c|c|c|c|}
\hline \multirow{2}{*}{\multicolumn{2}{|c|}{$($ age -55$) \times 1 / 2$}} & $(1)$ & $(2)$ & $(3)$ & $(4)$ & $(5)$ & $(6)$ \\
\hline & & $\begin{array}{c}8.66^{* * *} \\
(0.80)\end{array}$ & $\begin{array}{c}8.16^{* * *} \\
(0.80)\end{array}$ & $\begin{array}{c}7.32^{* * * *} \\
(0.88)\end{array}$ & $\begin{array}{c}6.79^{* * *} \\
(1.13)\end{array}$ & $\begin{array}{c}7.75^{* * * *} \\
(1.22)\end{array}$ & $\begin{array}{c}7.37^{* * * *} \\
(1.26)\end{array}$ \\
\hline \multicolumn{2}{|l|}{ Female } & $\begin{array}{l}1.52 \\
(2.59)\end{array}$ & $\begin{array}{l}1.62 \\
(2.55)\end{array}$ & $\begin{array}{l}5.68^{*} \\
(2.94)\end{array}$ & $\begin{array}{c}10.16^{* * * *} \\
(3.59)\end{array}$ & $\begin{array}{c}0.13 \\
(4.01)\end{array}$ & $\begin{array}{c}-0.53 \\
(4.36)\end{array}$ \\
\hline \multicolumn{2}{|l|}{ Below high school } & $\begin{array}{c}-14.86^{* * * *} \\
(2.85)\end{array}$ & $\begin{array}{c}-10.68^{* * *} \\
(2.92)\end{array}$ & $\begin{array}{c}-9.80^{* * * *} \\
(3.08)\end{array}$ & $\begin{array}{l}-6.11 \\
(3.94)\end{array}$ & $\begin{array}{c}-14.19^{* * *} \\
(3.82)\end{array}$ & $\begin{array}{c}-12.97^{* * * *} \\
(3.93)\end{array}$ \\
\hline \multicolumn{2}{|l|}{ Some college } & $\begin{array}{c}6.43^{* *} \\
(3.17)\end{array}$ & $\begin{array}{l}6.05^{*} \\
(3.16)\end{array}$ & $\begin{array}{c}5.31 \\
(3.23)\end{array}$ & $\begin{array}{c}9.33^{* *} \\
(3.77)\end{array}$ & $\begin{array}{l}-1.28 \\
(4.25)\end{array}$ & $\begin{array}{l}-2.30 \\
(4.43)\end{array}$ \\
\hline \multicolumn{2}{|l|}{ College } & $\begin{array}{c}11.60^{* * *} \\
(3.12)\end{array}$ & $\begin{array}{c}9.79^{* * *} \\
(3.18)\end{array}$ & $\begin{array}{c}10.91^{* * *} \\
(3.23)\end{array}$ & $\begin{array}{c}11.94^{* * *} \\
(3.90)\end{array}$ & $\begin{array}{l}8.24^{* *} \\
(4.05)\end{array}$ & $\begin{array}{c}6.99 \\
(4.51)\end{array}$ \\
\hline \multicolumn{2}{|l|}{ Single } & $\begin{array}{l}-4.52 \\
(5.45)\end{array}$ & $\begin{array}{l}-2.15 \\
(5.58)\end{array}$ & $\begin{array}{l}-0.81 \\
(5.81)\end{array}$ & $\begin{array}{l}-1.49 \\
(7.67)\end{array}$ & $\begin{array}{l}-1.69 \\
(7.97)\end{array}$ & $\begin{array}{c}0.72 \\
(7.95)\end{array}$ \\
\hline \multicolumn{2}{|l|}{ Black } & $\begin{array}{c}-11.35^{* * *} \\
(3.42)\end{array}$ & $\begin{array}{c}-7.73^{* *} \\
(3.37)\end{array}$ & $\begin{array}{l}-6.15^{*} \\
(3.70)\end{array}$ & $\begin{array}{l}-8.93^{*} \\
(4.61)\end{array}$ & $\begin{array}{l}-2.94 \\
(4.67)\end{array}$ & $\begin{array}{l}-5.78 \\
(4.71)\end{array}$ \\
\hline \multirow[t]{4}{*}{ Self-r. health: } & very good & & $\begin{array}{l}2.17 \\
(2.69)\end{array}$ & $\begin{array}{l}1.53 \\
(2.74)\end{array}$ & $\begin{array}{l}2.32 \\
(3.71)\end{array}$ & $\begin{array}{c}0.30 \\
(3.82)\end{array}$ & $\begin{array}{l}-0.83 \\
(3.90)\end{array}$ \\
\hline & good & & $\begin{array}{l}3.31 \\
(2.86)\end{array}$ & $\begin{array}{l}2.83 \\
(2.95)\end{array}$ & $\begin{array}{c}3.25 \\
(3.95)\end{array}$ & $\begin{array}{l}2.36 \\
(3.91)\end{array}$ & $\begin{array}{c}1.54 \\
(4.02)\end{array}$ \\
\hline & fair & & $\begin{array}{l}4.27 \\
(3.85)\end{array}$ & $\begin{array}{c}6.54 \\
(4.26)\end{array}$ & $\begin{array}{l}7.27 \\
(5.59)\end{array}$ & $\begin{array}{c}5.96 \\
(5.80)\end{array}$ & $\begin{array}{c}6.24 \\
(5.90)\end{array}$ \\
\hline & poor & & $\begin{array}{c}-11.40^{*} \\
(6.02)\end{array}$ & $\begin{array}{c}-13.47^{* *} \\
(6.16)\end{array}$ & $\begin{array}{c}0.35 \\
(9.32)\end{array}$ & $\begin{array}{c}-27.19^{* * *} \\
(5.72)\end{array}$ & $\begin{array}{c}-25.06^{* * * *} \\
(6.07)\end{array}$ \\
\hline \multirow[t]{3}{*}{ Wealth percentiles: } & $25-50$ & & $\begin{array}{c}10.58^{* * *} * \\
(2.71)\end{array}$ & $\begin{array}{c}10.15^{* * *} \\
(2.82)\end{array}$ & $\begin{array}{c}11.28^{* * *} \\
(3.87)\end{array}$ & $\begin{array}{c}7.78^{* *} \\
(3.81)\end{array}$ & $\begin{array}{c}8.52^{* *} \\
(3.95)\end{array}$ \\
\hline & $50-75$ & & $\begin{array}{c}18.98^{* * *} * \\
(3.04)\end{array}$ & $\begin{array}{c}18.54^{* * *} \\
(3.15)\end{array}$ & $\begin{array}{c}17.56^{* * *} \\
(4.05)\end{array}$ & $\begin{array}{c}18.42^{* * *} \\
(4.32)\end{array}$ & $\begin{array}{c}18.00^{* * *} \\
(4.46)\end{array}$ \\
\hline & $75-100$ & & $\begin{array}{c}17.05^{* * *} * \\
(3.38)\end{array}$ & $\begin{array}{c}17.24^{* * *} \\
(3.46)\end{array}$ & $\begin{array}{c}13.64^{* * *} \\
(4.34)\end{array}$ & $\begin{array}{c}20.32^{* * *} \\
(4.61)\end{array}$ & $\begin{array}{c}21.52^{* * * *} \\
(4.86)\end{array}$ \\
\hline \multicolumn{2}{|l|}{ Subjective $P_{75}$} & & & $\begin{array}{l}-1.77 \\
(3.03)\end{array}$ & $\begin{array}{c}0.28 \\
(3.96)\end{array}$ & $\begin{array}{l}-4.83 \\
(4.00)\end{array}$ & $\begin{array}{l}-6.08 \\
(4.15)\end{array}$ \\
\hline \multicolumn{2}{|l|}{ Experience } & & & $\begin{array}{c}0.51^{* * *} \\
(0.14)\end{array}$ & $\begin{array}{c}0.53^{* * *} \\
(0.18)\end{array}$ & $\begin{array}{c}0.45^{* *} \\
(0.19)\end{array}$ & $\begin{array}{c}0.39 * * \\
(0.19)\end{array}$ \\
\hline \multirow[t]{4}{*}{ Financial time horizon } & few months & & & & & $\begin{array}{c}-13.39^{* *} \\
(6.41)\end{array}$ & $\begin{array}{c}-14.39^{* *} \\
(6.63)\end{array}$ \\
\hline & year & & & & & $\begin{array}{r}-10.72 \\
(6.69)\end{array}$ & $\begin{array}{c}-9.44 \\
(6.99)\end{array}$ \\
\hline & few years & & & & & $\begin{array}{c}-10.56^{*} \\
(5.64)\end{array}$ & $\begin{array}{c}-11.74^{* *} \\
(5.84)\end{array}$ \\
\hline & $5-10$ years & & & & & $\begin{array}{l}-5.72 \\
(5.72)\end{array}$ & $\begin{array}{l}-7.23 \\
(5.94)\end{array}$ \\
\hline \multicolumn{3}{|c|}{ Receives a pension } & & & $\begin{array}{c}6.94 \\
(4.30)\end{array}$ & & \\
\hline \multicolumn{2}{|c|}{ Pension on current job } & & & & $\begin{array}{c}2.41 \\
(2.80)\end{array}$ & & \\
\hline Occupation dummies & & no & no & no & no & no & yes \\
\hline Observations & & 5466 & 5466 & 4990 & 2018 & 2346 & 2190 \\
\hline R-squared & & 0.12 & 0.14 & 0.14 & 0.14 & 0.16 & 0.18 \\
\hline
\end{tabular}

Notes: Clustered (by individual) standard errors in parentheses. Sample: HRS 1992-1994, age 55-65. The excluded categories are workers with a high school (HS) degree, in excellent health, with net wealth in the first quartile, and a financial time horizon of more than 10 years. The subjective probability of surviving until age $75, P_{75}$, is divided by the implied probability from the Vital Statistics life tables that someone of the respondent's age and gender will live to be 75 . 
Table 3: Linear probability (in percent) model of being unable to provide a benefit estimate.

\begin{tabular}{|c|c|c|c|c|c|c|}
\hline & (1) & $(2)$ & $(3)$ & $(4)$ & $(5)$ & $(6)$ \\
\hline & \multicolumn{6}{|c|}{ Does not report and expected Social Security benefit amount } \\
\hline \multirow[t]{2}{*}{ Post-Statement } & $-4.29 * *$ & -4.30 & $-4.75^{*}$ & -0.19 & 5.58 & 5.83 \\
\hline & $(1.87)$ & $(2.82)$ & $(2.82)$ & $(2.24)$ & $(4.83)$ & $(4.86)$ \\
\hline \multirow[t]{2}{*}{ No SSA contact } & & & & $26.19^{* * *}$ & $26.73^{* * *}$ & $25.67^{* * *}$ \\
\hline & & & & $(2.62)$ & $(2.59)$ & $(2.59)$ \\
\hline \multirow[t]{2}{*}{ Post $\times$ no SSA c. } & & & & $-10.93^{* * *}$ & $-11.58^{* * *}$ & $-11.81^{* * *}$ \\
\hline & & & & $(3.06)$ & $(3.06)$ & $(3.04)$ \\
\hline \multirow[t]{2}{*}{ Female } & $5.78^{* * *}$ & $5.61^{* * *}$ & $6.27^{* * *}$ & $6.15^{* *}$ & $5.97 * *$ & $6.27^{* *}$ \\
\hline & (1.97) & $(1.96)$ & $(1.94)$ & $(2.49)$ & $(2.48)$ & $(2.45)$ \\
\hline \multirow[t]{2}{*}{ Below HS } & $11.55^{* * *}$ & $11.46^{* * *}$ & $8.79^{* * *}$ & $10.09^{* * *}$ & $9.90^{* * *}$ & $7.70^{* *}$ \\
\hline & $(2.26)$ & $(2.26)$ & $(2.28)$ & $(2.97)$ & $(2.97)$ & $(3.01)$ \\
\hline \multirow[t]{2}{*}{ Some college } & -0.44 & -0.52 & -0.13 & -1.62 & -1.58 & -1.51 \\
\hline & $(2.03)$ & $(2.03)$ & $(2.03)$ & $(2.44)$ & $(2.44)$ & $(2.42)$ \\
\hline \multirow[t]{2}{*}{ College } & -0.18 & -0.40 & 1.31 & 0.84 & 0.59 & 1.71 \\
\hline & $(2.01)$ & $(2.01)$ & $(2.06)$ & $(2.40)$ & $(2.39)$ & $(2.43)$ \\
\hline \multirow[t]{2}{*}{ Single } & 4.55 & 4.68 & 3.14 & 7.24 & 7.00 & 4.59 \\
\hline & $(4.19)$ & (4.18) & $(4.15)$ & $(6.44)$ & $(6.43)$ & $(6.48)$ \\
\hline \multirow[t]{2}{*}{ Black } & $13.10^{* * *}$ & $13.27 * * *$ & $11.00^{* * *}$ & $9.74^{* * *}$ & $9.75^{* * *}$ & $8.17^{* *}$ \\
\hline & $(2.75)$ & $(2.76)$ & $(2.75)$ & $(3.43)$ & $(3.47)$ & $(3.43)$ \\
\hline Wealth & no & no & yes & no & no & yes \\
\hline Health & no & no & yes & no & no & yes \\
\hline Age effects & no & yes & yes & no & yes & yes \\
\hline Year effects & no & yes & yes & no & yes & yes \\
\hline Observations & 5311 & 5311 & 5311 & 3196 & 3196 & 3196 \\
\hline R-squared & 0.054 & 0.058 & 0.067 & 0.103 & 0.108 & 0.116 \\
\hline
\end{tabular}

Notes: The non-numbered column reports the sample means. The excluded educational category is high school. Clustered (by individual) standard errors in parentheses; Bootstrapping (using 200 rep.) the standard errors by individual to account for both clustering, and also for the variation due to the first-step estimation of the probabilities of misclassification of contacting the SSA has negligible effects on the standard errors (results available upon request). ${ }^{*}$ significant at 5 percent; ${ }^{* *}$ significant at 1 percent. Sample: HRS 1992-2002, age 55-65. 
Table 4: Linear probability (in percent) model of not being able to provide a Social Security benefits estimate by age.

\begin{tabular}{|c|c|c|c|c|c|c|c|}
\hline \multirow[b]{2}{*}{ Age } & \multirow{2}{*}{$\begin{array}{c}\text { Contacted } \\
\text { SSA }\end{array}$} & \multicolumn{3}{|c|}{ Contacted SSA } & \multicolumn{3}{|c|}{ Did not contact SSA } \\
\hline & & Pre-SSS & Pre-Post & Pre-Post & Pre-SSS & Pre-Post & Pre-Post \\
\hline \multirow[t]{2}{*}{55} & 0.28 & $21.18^{* * *}$ & -5.20 & -5.49 & $50.78^{* * *}$ & -7.39 & -4.95 \\
\hline & & $(3.80)$ & $(10.00)$ & $(9.98)$ & $(2.90)$ & $(9.82)$ & $(9.88)$ \\
\hline \multirow[t]{2}{*}{56} & 0.31 & $17.54^{* * *}$ & 3.84 & 4.32 & $52.33^{* * *}$ & -0.25 & -0.27 \\
\hline & & $(3.63)$ & $(9.28)$ & $(9.30)$ & $(3.05)$ & $(8.75)$ & $(8.65)$ \\
\hline \multirow[t]{2}{*}{57} & 0.30 & $19.36^{* * *}$ & -5.13 & -4.16 & $47.49 * * *$ & 10.86 & $12.50^{* *}$ \\
\hline & & $(3.23)$ & $(6.13)$ & $(6.08)$ & $(2.71)$ & $(6.61)$ & $(6.32)$ \\
\hline \multirow[t]{2}{*}{58} & 0.42 & $22.53^{* * *}$ & $-11.58^{* * *}$ & $-10.24^{* *}$ & $52.53^{* * *}$ & $-9.08^{*}$ & -7.76 \\
\hline & & $(3.37)$ & $(4.39)$ & $(4.50)$ & $(3.67)$ & $(4.92)$ & $(4.89)$ \\
\hline \multirow[t]{2}{*}{59} & 0.42 & $19.07 * * *$ & 1.17 & 4.50 & $56.81 * * *$ & $-17.48^{* * *}$ & $-15.36^{* * *}$ \\
\hline & & $(3.32)$ & $(4.37)$ & $(4.39)$ & $(3.62)$ & $(4.49)$ & $(4.49)$ \\
\hline \multirow[t]{2}{*}{60} & 0.39 & $15.04^{* * *}$ & -4.36 & -1.84 & $57.11^{* * *}$ & $-14.43^{* * *}$ & $-12.35^{* *}$ \\
\hline & & $(3.05)$ & $(3.59)$ & $(3.81)$ & $(4.04)$ & $(4.83)$ & $(5.01)$ \\
\hline \multirow[t]{2}{*}{61} & 0.55 & $9.94^{* * *}$ & 4.06 & $7.89^{* *}$ & $57.50 * * *$ & $-23.22^{* * *}$ & $-19.20 * * *$ \\
\hline & & $(2.29)$ & $(2.97)$ & $(3.29)$ & $(4.53)$ & $(5.09)$ & $(5.14)$ \\
\hline \multirow[t]{2}{*}{62} & 0.59 & $12.15^{* * *}$ & -0.84 & 3.19 & $57.14^{* * *}$ & $-24.88^{* * *}$ & $-21.07 * * *$ \\
\hline & & $(3.17)$ & $(3.96)$ & $(4.21)$ & $(5.93)$ & $(6.69)$ & $(6.97)$ \\
\hline \multirow[t]{2}{*}{63} & 0.66 & $11.59^{* * *}$ & 0.35 & 3.21 & $52.63^{* * *}$ & $-20.56^{* *}$ & $-17.09^{*}$ \\
\hline & & $(3.87)$ & $(4.62)$ & $(4.81)$ & $(8.12)$ & $(8.79)$ & $(8.84)$ \\
\hline \multirow[t]{2}{*}{64} & 0.67 & 14.29 & -0.89 & -1.73 & $33.33^{* *}$ & 4.44 & 1.50 \\
\hline & & $(9.38)$ & $(9.81)$ & $(9.51)$ & $(15.76)$ & $(16.30)$ & $(16.39)$ \\
\hline \multicolumn{2}{|c|}{ Other Xs } & & no & yes & & no & yes \\
\hline
\end{tabular}

Notes: The first column reports the fraction contacting the SSA. "Pre" columns report the fraction of workers who do not provide an estimate during the Pre-Statement period. Pre-Post columns report changes in the probability of providing a benefit estimate. Fractions are computed separately for workers who contacted (first three columns) and those who didn't contact the SSA (last three columns). Clustered (by individual) standard errors in parentheses. Bootstrapping (using 200 rep.) the standard errors by individual to account for both clustering, and for the variation due to the first-step estimation of the probabilities of misclassification of contacting the SSA has negligible effects on the significance level (results available upon request). ${ }^{*}$ significant at 5 percent; ${ }^{* *}$ significant at 1 percent. Sample: HRS 1992-2002, age 55-64. 
Table 5: Variance ratio test

\begin{tabular}{|c|c|c|c|c|c|c|}
\hline & \multicolumn{3}{|c|}{ Did not contact SSA } & \multicolumn{3}{|c|}{ Contacted SSA } \\
\hline & \multicolumn{2}{|c|}{ Standard Dev. } & \multirow{2}{*}{$\begin{array}{c}\text { p-value } \\
\text { Pre/Post }\end{array}$} & \multicolumn{2}{|c|}{ Standard Dev. } & \multirow{3}{*}{$\begin{array}{c}\mathrm{p} \text {-value } \\
\text { Pre/Post }\end{array}$} \\
\hline & Pre-SSS & Post-SSS & & Pre-SSS & Post-SSS & \\
\hline \multicolumn{6}{|c|}{ Forecast error truncated at: } & \\
\hline$|e|<\$ 1000$ & $\begin{array}{c}477.24 \\
{[625]}\end{array}$ & $\begin{array}{c}330.26 \\
{[265]}\end{array}$ & 0.000 & $\begin{array}{c}626.15 \\
{[779]}\end{array}$ & $\begin{array}{c}759.22 \\
{[254]}\end{array}$ & 1.000 \\
\hline$|e|<\$ 500$ & $\begin{array}{c}226.93 \\
{[518]}\end{array}$ & $\begin{array}{c}204.17 \\
{[232]}\end{array}$ & 0.032 & $\begin{array}{c}182.42 \\
{[701]}\end{array}$ & $\begin{array}{c}171.40 \\
{[240]}\end{array}$ & 0.125 \\
\hline$|e|<\$ 300$ & $\begin{array}{c}154.04 \\
{[398]}\end{array}$ & $\begin{array}{c}136.24 \\
{[196]}\end{array}$ & 0.026 & $\begin{array}{c}129.02 \\
{[610]}\end{array}$ & $\begin{array}{c}123.14 \\
{[213]}\end{array}$ & 0.211 \\
\hline
\end{tabular}

Notes: Standard deviation of the errors and p-value of a variance ratio test with null-hypothesis $H_{0}: V_{\text {pre }} / V_{\text {post }}<1$. Estimates control for the improvement in the standard deviation of the forecast error that is independent of the Statement by using the dashed line version of Figure 1 for the pre-Statement period. Since variances are highly sensitive to outliers I test the null using three truncated versions of the forecast error. Numbers of observations in square brackets. Sample: HRS 1992-1996, age 55-65. 
Table 6: Marginal effects (in percent) on the probability of keeping the same expected age of claiming.

\begin{tabular}{lcccc}
\hline \hline & \multicolumn{3}{c}{$P($ same expected claiming age $)$} \\
& $(1)$ & $(2)$ & $(3)$ & $(4)$ \\
\hline Post-statement & 0.77 & -0.02 & 1.06 & 0.25 \\
& $(3.05)$ & $(3.94)$ & $(3.18)$ & $(4.44)$ \\
Post-st. × No SSA cont. & & 0.43 & & 0.15 \\
& & $(4.21)$ & & $(4.48)$ \\
Additional statement & & & 1.44 & 0.00 \\
& & & $(2.93)$ & $(4.84)$ \\
Add. st. × No SSA cont. & & & & 0.68 \\
& & & & $(5.28)$ \\
No SSA contact & & $-7.02^{* *}$ & & $-7.02^{* *}$ \\
& & $(3.25)$ & & $(3.25)$ \\
ETdummy & -3.10 & -0.92 & -3.21 & -0.82 \\
& $(3.46)$ & $(4.54)$ & $(3.46)$ & $(4.79)$ \\
Year & -0.46 & 0.36 & -0.69 & 0.28 \\
& $(0.83)$ & $(1.04)$ & $(0.97)$ & $(1.52)$ \\
Observations & 3624 & 2524 & 3624 & 2524 \\
Mean & 66.78 & 67.23 & 66.78 & 67.23 \\
R-squared & 0.025 & 0.036 & 0.025 & 0.036 \\
\hline
\end{tabular}

Notes: The marginal effects are estimated using a linear probability model. I additionally control for age, age squared, education, marital status, race, and veteran status. Clustered (by individuals) standard errors in parentheses; ${ }^{*}$ significant at 5 percent; ${ }^{* *}$ significant at 1 percent. Sample: HRS 1992-2002, age 55-65. 
Table 7: Median expected growth rates of Social Security benefits and social security wealth as a function of age.

\begin{tabular}{|c|c|c|c|c|c|c|c|}
\hline \multirow[t]{4}{*}{. } & \multirow{4}{*}{$\mathrm{B}(\mathrm{t}+1) / \mathrm{B}(\mathrm{t})-1$} & \multicolumn{6}{|c|}{ Accruals $=\mathrm{SSW}(\mathrm{t}+1)-\mathrm{SSW}(\mathrm{t})$} \\
\hline & & \multirow{2}{*}{\multicolumn{2}{|c|}{$\begin{array}{l}\text { Own Benefits } \\
\text { Median }\end{array}$}} & \multicolumn{4}{|c|}{ Own+Dependent spouse } \\
\hline & & & & \multicolumn{2}{|c|}{ Median } & \multicolumn{2}{|c|}{ 75th percentile } \\
\hline & & Pre-tax & After-tax & Pre-tax & After-tax & Pre-tax & After-tax \\
\hline 55 & 1.36 & 1.25 & -0.92 & 1.41 & -0.65 & 2.76 & 0 \\
\hline 56 & 1.06 & 0.99 & -0.65 & 1.14 & -0.44 & 2.54 & 0 \\
\hline 57 & 0.94 & 0.86 & -0.64 & 0.99 & -0.39 & 2.53 & 0 \\
\hline 58 & 0.71 & 0.65 & -0.55 & 0.73 & -0.3 & 2.39 & 0 \\
\hline 59 & 0.53 & 0.51 & -0.37 & 0.57 & -0.17 & 2.29 & 0 \\
\hline 60 & 0.4 & 0.36 & -0.3 & 0.39 & -0.12 & 2.18 & 0 \\
\hline 61 & 0.26 & 0.19 & -0.18 & 0.21 & -0.02 & 2.11 & 0 \\
\hline 62 & 8.71 & 1.66 & 0.72 & 2.79 & 1.37 & 8.69 & 6.22 \\
\hline 63 & 7.87 & 0.27 & -0.42 & 1.58 & 0.59 & 6.61 & 4.09 \\
\hline 64 & 7.22 & -0.8 & -1.7 & 0.25 & 0 & 3.76 & 1.86 \\
\hline 65 & 5.94 & -3.72 & -4.42 & -2.08 & -2.85 & 0 & -0.89 \\
\hline 66 & 5.25 & -5.48 & -6.04 & -3.87 & -4.66 & -1.41 & -2.16 \\
\hline 67 & 4.94 & -7.05 & -7.6 & -5.78 & -6.5 & -2.59 & -3.26 \\
\hline 68 & 4.43 & -8.45 & -8.97 & -7.59 & -8.34 & -4.09 & -4.63 \\
\hline 69 & 4.18 & -9.66 & -10.23 & -9.38 & -9.87 & -5.05 & -5.48 \\
\hline
\end{tabular}

Notes: The After-tax columns represent the changes in SSW net of Social Security payroll taxes, assuming that workers carry the whole tax burden. Sample: HRS 1992-2002 linked to administrative data.

Table 8: Summary statistics of Social Security Incentives

\begin{tabular}{lccc}
\hline \hline \multicolumn{1}{c}{ Variable } & Mean & Std. Dev. & N \\
\hline Yearly percentage increase in benefits (in \%) & 4.004 & 3.537 & 31563 \\
Percentage accrual, 3\%, single & 0.05 & 2.592 & 31563 \\
Percentage accrual, 3\%, joint & 0.523 & 2.526 & 31563 \\
Accrual, 3\%, single $(\$ 1,000)$ & -0.534 & 3.907 & 33118 \\
Accrual, 3\%, joint $(\$ 1,000)$ & 0.592 & 5.124 & 33118 \\
Percentage after-tax accrual, 3\%, single & -1.468 & 2.279 & 31563 \\
Percentage after-tax accrual, 3\%, joint & -0.758 & 2.238 & 31563 \\
After-tax accrual, 3\%, single $(\$ 1,000)$ & -2.65 & 4.035 & 33118 \\
After-tax accrual, 3\%, joint $(\$ 1,000)$ & -1.524 & 4.969 & 33118 \\
Peak value, 3\%, single $(\$ 1,000)$ & 3.003 & 8.833 & 33118 \\
Peak value, 3\%, joint $(\$ 1,000)$ & 10.117 & 18.45 & 33118 \\
Social Security Wealth, 3\%, joint $(\$ 100,000)$ & 1.747 & 1.115 & 33118 \\
Spouse SSW at age $62(\$ 100,000), 3 \%$ & 0.34 & 0.557 & 33118 \\
Forecasted real earnings $($ maximum) $(\$ 1,000)$ & 17.064 & 24.012 & 33118 \\
\hline
\end{tabular}


Table 9: Sample size

\begin{tabular}{|c|c|c|c|c|c|c|c|c|c|c|c|c|c|c|c|}
\hline & 55 & 56 & 57 & 58 & 59 & 60 & 61 & 62 & 63 & 64 & 65 & 66 & 67 & 68 & 69 \\
\hline 1922 & & & & & & & & & & & & & & & 4 \\
\hline 1923 & & & & & & & & & & & & & & 5 & 19 \\
\hline 1924 & & & & & & & & & & & & & 9 & 19 & 29 \\
\hline 1925 & & & & & & & & & & & & 7 & 20 & 23 & 22 \\
\hline 1926 & & & & & & & & & & & 6 & 25 & 38 & 35 & 34 \\
\hline 1927 & & & & & & & & & & 12 & 41 & 50 & 44 & 44 & 41 \\
\hline 1928 & & & & & & & & & 24 & 83 & 97 & 90 & 80 & 74 & 98 \\
\hline 1929 & & & & & & & & 20 & 88 & 104 & 79 & 78 & 82 & 104 & 109 \\
\hline 1930 & & & & & & & 39 & 128 & 146 & 126 & 119 & 115 & 145 & 153 & 163 \\
\hline 1931 & & & & & & 91 & 314 & 347 & 292 & 278 & 279 & 310 & 253 & 254 & 240 \\
\hline 1932 & & & & & 87 & 344 & 384 & 323 & 311 & 295 & 329 & 262 & 269 & 251 & 203 \\
\hline 1933 & & & & 84 & 312 & 351 & 282 & 267 & 265 & 289 & 251 & 266 & 235 & 180 & 208 \\
\hline 1934 & & & 108 & 355 & 402 & 343 & 332 & 328 & 342 & 306 & 321 & 284 & 226 & 266 & 148 \\
\hline 1935 & & 97 & 379 & 429 & 354 & 336 & 334 & 381 & 318 & 320 & 294 & 239 & 274 & 151 & \\
\hline 1936 & 102 & 408 & 443 & 374 & 358 & 351 & 402 & 334 & 327 & 324 & 277 & 311 & 190 & & \\
\hline 1937 & 323 & 483 & 405 & 391 & 376 & 411 & 349 & 360 & 340 & 283 & 323 & 184 & & & \\
\hline 1938 & 187 & 396 & 370 & 362 & 390 & 348 & 357 & 332 & 272 & 316 & 176 & 1 & & & \\
\hline 1939 & 239 & 379 & 379 & 414 & 367 & 378 & 340 & 296 & 325 & 182 & 2 & & & & \\
\hline 1940 & 150 & 368 & 418 & 369 & 381 & 350 & 289 & 349 & 200 & & & & & & \\
\hline 1941 & 232 & 431 & 390 & 402 & 362 & 291 & 351 & 213 & 3 & & & & & & \\
\hline
\end{tabular}

Notes: The treatment and control sample is shown in bold and is made of age-year of birth combinations in which some, but not all individuals received a Social Security statement. 56 percent of this sample received a statement. 
Table 10: Randomization Test

\begin{tabular}{lcccc}
\hline & \multicolumn{2}{c}{ Pre-Statement } & \multicolumn{2}{c}{ Post-pre Statement } \\
& Average & SE & Average & SE \\
\hline Female & $0.331^{* * *}$ & $(0.0301)$ & -0.0120 & $(0.0176)$ \\
Married & $0.954^{* * *}$ & $(0.0133)$ & 0.00436 & $(0.00751)$ \\
Spouse in inactive & $0.304^{* * *}$ & $(0.0292)$ & -0.0247 & $(0.0182)$ \\
Independent spouse & $0.691^{* * *}$ & $(0.0291)$ & -0.00227 & $(0.0170)$ \\
Experience & $34.06^{* * *}$ & $(0.473)$ & -0.382 & $(0.308)$ \\
No kids & $0.0460^{* * *}$ & $(0.0114)$ & $0.0197^{* *}$ & $(0.00810)$ \\
Black & $0.0876^{* * *}$ & $(0.0179)$ & -0.0139 & $(0.0115)$ \\
High school & $0.348^{* * *}$ & $(0.0302)$ & -0.00623 & $(0.0176)$ \\
Some college & $0.178^{* * *}$ & $(0.0245)$ & -0.00429 & $(0.0152)$ \\
College & $0.292^{* * *}$ & $(0.0284)$ & 0.0177 & $(0.0158)$ \\
Veteran & $0.310^{* * *}$ & $(0.0292)$ & -0.0198 & $(0.0178)$ \\
SR health status: very good & $0.383^{* * *}$ & $(0.0304)$ & -0.0182 & $(0.0180)$ \\
SR health status: good & $0.223^{* * *}$ & $(0.0258)$ & -0.0273 & $(0.0170)$ \\
SR health status: fair & $0.0698^{* * *}$ & $(0.0157)$ & 0.0143 & $(0.0113)$ \\
SR health status: poor & 0.00390 & $(0.00407)$ & $-0.00732^{*}$ & $(0.00407)$ \\
Average ET tax & 0 & 0 & -0.000131 & $(0.000140)$ \\
Spouse's age-own age & -0.0514 & $(0.0767)$ & $0.164^{* * *}$ & $(0.0555)$ \\
\hline
\end{tabular}

Notes: Each line represents a different regression of the "row" variable regressed on year, year squared, age dummies, and the Statement dummy (the Post-pre column). Clustered (by individual) standard errors in parentheses; ${ }^{*}$ significant at 5 percent; ${ }^{* *}$ significant at 1 percent. Sample: HRS linked to administrative data. 
Table 11: Linear probability model of retirement.

\begin{tabular}{|c|c|c|c|c|c|}
\hline & \multirow[t]{2}{*}{$(1)$} & $(2)$ & $(3)$ & $(4)$ & \multirow{2}{*}{ t) } \\
\hline & & f-reported $\mathrm{r}$ & tirement $\mathrm{h}$ & azard (in per & \\
\hline Yearly percentage increase in benefits & $\begin{array}{c}-0.537^{* * *} \\
(0.170)\end{array}$ & & & & \\
\hline Percentage accrual & & $\begin{array}{c}-0.554^{* * *} \\
(0.178)\end{array}$ & & & \\
\hline Accrual & & & $\begin{array}{c}-0.337^{*} \\
(0.204)\end{array}$ & & \\
\hline Percentage after-tax accrual & & & & $\begin{array}{c}-0.599^{* *} \\
(0.257)\end{array}$ & \\
\hline Peak value & & & & & $\begin{array}{c}-0.0757^{* * *} * \\
(0.0250)\end{array}$ \\
\hline Social Security Wealth & $\begin{array}{c}1.052 \\
(2.019)\end{array}$ & $\begin{array}{c}1.666 \\
(1.992)\end{array}$ & $\begin{array}{c}2.152 \\
(2.077)\end{array}$ & $\begin{array}{c}1.759 \\
(1.993)\end{array}$ & $\begin{array}{c}0.736 \\
(2.013)\end{array}$ \\
\hline Spouse SSW at age 62 & $\begin{array}{c}0.600 \\
(0.765)\end{array}$ & $\begin{array}{c}0.655 \\
(0.764)\end{array}$ & $\begin{array}{c}0.694 \\
(0.766)\end{array}$ & $\begin{array}{c}0.600 \\
(0.765)\end{array}$ & $\begin{array}{c}0.556 \\
(0.764)\end{array}$ \\
\hline Forecasted real earnings & $\begin{array}{l}-0.0152 \\
(0.0156)\end{array}$ & $\begin{array}{l}-0.0143 \\
(0.0155)\end{array}$ & $\begin{array}{l}-0.0182 \\
(0.0178)\end{array}$ & $\begin{array}{c}-0.0568^{* * *} \\
(0.0151)\end{array}$ & $\begin{array}{l}-0.0115 \\
(0.0162)\end{array}$ \\
\hline Female & $\begin{array}{l}2.367^{*} \\
(1.253)\end{array}$ & $\begin{array}{l}2.407^{*} \\
(1.250)\end{array}$ & $\begin{array}{l}2.226^{*} \\
(1.243)\end{array}$ & $\begin{array}{l}2.427^{*} \\
(1.249)\end{array}$ & $\begin{array}{c}2.708^{* *} \\
(1.263)\end{array}$ \\
\hline Married & $\begin{array}{l}-1.105 \\
(1.538)\end{array}$ & $\begin{array}{c}-1.153 \\
(1.537)\end{array}$ & $\begin{array}{c}-1.179 \\
(1.534)\end{array}$ & $\begin{array}{l}-1.129 \\
(1.539)\end{array}$ & $\begin{array}{l}-1.199 \\
(1.537)\end{array}$ \\
\hline Spouse is not active & $\begin{array}{c}2.622^{* * *} * \\
(0.643)\end{array}$ & $\begin{array}{c}2.649^{* * *} \\
(0.643)\end{array}$ & $\begin{array}{c}2.636^{* * *} \\
(0.644)\end{array}$ & $\begin{array}{c}2.658^{* * *} \\
(0.644)\end{array}$ & $\begin{array}{c}2.525^{* * *} \\
(0.641)\end{array}$ \\
\hline Independent spouse & $\begin{array}{c}0.503 \\
(2.120)\end{array}$ & $\begin{array}{c}0.796 \\
(2.108)\end{array}$ & $\begin{array}{c}0.947 \\
(2.136)\end{array}$ & $\begin{array}{c}0.360 \\
(2.126)\end{array}$ & $\begin{array}{c}-1.904 \\
(2.258)\end{array}$ \\
\hline Experience & $\begin{array}{c}0.0348 \\
(0.0363)\end{array}$ & $\begin{array}{c}0.0347 \\
(0.0364)\end{array}$ & $\begin{array}{c}0.0419 \\
(0.0363)\end{array}$ & $\begin{array}{c}0.0379 \\
(0.0365)\end{array}$ & $\begin{array}{c}0.0392 \\
(0.0363)\end{array}$ \\
\hline No children & $\begin{array}{c}-0.981 \\
(1.208)\end{array}$ & $\begin{array}{c}-0.964 \\
(1.210)\end{array}$ & $\begin{array}{c}-0.950 \\
(1.209)\end{array}$ & $\begin{array}{c}-0.992 \\
(1.207)\end{array}$ & $\begin{array}{c}-1.033 \\
(1.207)\end{array}$ \\
\hline Black & $\begin{array}{c}0.441 \\
(0.920)\end{array}$ & $\begin{array}{c}0.424 \\
(0.919)\end{array}$ & $\begin{array}{c}0.492 \\
(0.919)\end{array}$ & $\begin{array}{c}0.472 \\
(0.920)\end{array}$ & $\begin{array}{c}0.512 \\
(0.921)\end{array}$ \\
\hline High school & $\begin{array}{l}-0.0822 \\
(0.787)\end{array}$ & $\begin{array}{l}-0.104 \\
(0.787)\end{array}$ & $\begin{array}{l}-0.0237 \\
(0.788)\end{array}$ & $\begin{array}{c}-0.0413 \\
(0.787)\end{array}$ & $\begin{array}{l}-0.0268 \\
(0.788)\end{array}$ \\
\hline Some college & $\begin{array}{l}1.448 \\
(0.964)\end{array}$ & $\begin{array}{l}1.444 \\
(0.964)\end{array}$ & $\begin{array}{l}1.524 \\
(0.965)\end{array}$ & $\begin{array}{l}1.509 \\
(0.965)\end{array}$ & $\begin{array}{c}1.515 \\
(0.964)\end{array}$ \\
\hline College & $\begin{array}{l}1.795 \\
(1.202)\end{array}$ & $\begin{array}{l}1.823 \\
(1.203)\end{array}$ & $\begin{array}{c}1.922 \\
(1.204)\end{array}$ & $\begin{array}{l}1.868 \\
(1.203)\end{array}$ & $\begin{array}{c}1.896 \\
(1.203)\end{array}$ \\
\hline Veteran & $\begin{array}{c}0.341 \\
(0.706)\end{array}$ & $\begin{array}{c}0.354 \\
(0.706)\end{array}$ & $\begin{array}{c}0.330 \\
(0.706)\end{array}$ & $\begin{array}{c}0.311 \\
(0.706)\end{array}$ & $\begin{array}{c}0.368 \\
(0.707)\end{array}$ \\
\hline Average forecasted ET tax & $\begin{array}{c}8.854 \\
(104.8)\end{array}$ & $\begin{array}{c}7.025 \\
(104.9)\end{array}$ & $\begin{array}{c}23.93 \\
(105.7)\end{array}$ & $\begin{array}{c}24.40 \\
(105.5)\end{array}$ & $\begin{array}{c}-22.74 \\
(105.2)\end{array}$ \\
\hline Spouse age-own age & $\begin{array}{c}-0.734^{* *} \\
(0.342)\end{array}$ & $\begin{array}{c}-0.740^{* *} \\
(0.342)\end{array}$ & $\begin{array}{c}-0.750^{* *} \\
(0.342)\end{array}$ & $\begin{array}{c}-0.730^{* *} \\
(0.342)\end{array}$ & $\begin{array}{c}-0.744^{* *} \\
(0.343)\end{array}$ \\
\hline N.obs & 6359 & 6359 & 6359 & 6359 & 6359 \\
\hline R-squared & 0.064 & 0.064 & 0.064 & 0.064 & 0.064 \\
\hline
\end{tabular}

Notes: All Social Security incentives are expressed in real 2003 dollars. All regressions additionally control for real AIME, spouse's real AIME, age dummies, year, year squared, industry and occupation dummies, and self-reported health dummies. Clustered (by individual) standard errors in parentheses; * significant at 5 percent; ${ }^{* *}$ significant at 1 percent. Sample: HRS linked to administrative data. 
Table 12: Pre-Post Statement model of retirement.

\begin{tabular}{|c|c|c|c|c|c|}
\hline & $(1)$ & $(2)$ & $(3)$ & $(4)$ & $(5)$ \\
\hline & \multicolumn{5}{|c|}{ Self-reported retirement hazard } \\
\hline Yearly percentage increase in benefits & $\begin{array}{c}-0.453^{* *} \\
(0.202)\end{array}$ & & & & \\
\hline interacted with the Statement & $\begin{array}{l}-0.164 \\
(0.219)\end{array}$ & & & & \\
\hline Percentage accrual & & $\begin{array}{c}-0.450^{*} \\
(0.236)\end{array}$ & & & \\
\hline interacted with the Statement & & $\begin{array}{l}-0.185 \\
(0.301)\end{array}$ & & & \\
\hline Accrual & & & $\begin{array}{l}-0.226 \\
(0.265)\end{array}$ & & \\
\hline interacted with the Statement & & & $\begin{array}{l}-0.175 \\
(0.274)\end{array}$ & & \\
\hline Relative after-tax accrual & & & & $\begin{array}{l}-0.542 \\
(0.333)\end{array}$ & \\
\hline interacted with the Statement & & & & $\begin{array}{l}-0.113 \\
(0.371)\end{array}$ & \\
\hline Peak value & & & & & $\begin{array}{c}-0.0729^{* *} \\
(0.0290)\end{array}$ \\
\hline interacted with the Statement & & & & & $\begin{array}{c}-0.00672 \\
(0.0347)\end{array}$ \\
\hline Social Security Wealth & $\begin{array}{c}0.920 \\
(2.082)\end{array}$ & $\begin{array}{l}1.588 \\
(2.066)\end{array}$ & $\begin{array}{l}1.922 \\
(2.151)\end{array}$ & $\begin{array}{l}1.718 \\
(2.071)\end{array}$ & $\begin{array}{c}0.643 \\
(2.133)\end{array}$ \\
\hline interacted with the Statement & $\begin{array}{c}0.147 \\
(0.770)\end{array}$ & $\begin{array}{l}0.0851 \\
(0.784)\end{array}$ & $\begin{array}{c}0.234 \\
(0.817)\end{array}$ & $\begin{array}{c}0.0816 \\
(0.784)\end{array}$ & $\begin{array}{c}0.146 \\
(1.004)\end{array}$ \\
\hline Forecasted real earnings (maximum) & $\begin{array}{l}-0.0148 \\
(0.0155)\end{array}$ & $\begin{array}{l}-0.0143 \\
(0.0155)\end{array}$ & $\begin{array}{l}-0.0190 \\
(0.0178)\end{array}$ & $\begin{array}{c}-0.0565^{* * *} \\
(0.0151)\end{array}$ & $\begin{array}{l}-0.0110 \\
(0.0162)\end{array}$ \\
\hline Statement & $\begin{array}{c}-0.592 \\
(1.501) \\
\end{array}$ & $\begin{array}{c}-0.719 \\
(1.548) \\
\end{array}$ & $\begin{array}{c}-0.879 \\
(1.446) \\
\end{array}$ & $\begin{array}{c}-0.994 \\
(1.443) \\
\end{array}$ & $\begin{array}{l}-0.925 \\
(1.463) \\
\end{array}$ \\
\hline N.obs & 6359 & 6359 & 6359 & 6359 & 6359 \\
\hline R-squared & 0.070 & 0.071 & 0.070 & 0.070 & 0.070 \\
\hline
\end{tabular}

Notes: Additional controls as in Table 11. Clustered (by individuals) standard errors in parentheses, ${ }^{*}$ significant at 5 percent; ${ }^{* *}$ significant at 1 percent. Sample: HRS linked to administrative data. 


\section{A Data}

I use the Health and Retirement Survey (HRS) to evaluate how the Statement affects workers' knowledge about their future benefits, and to evaluate what determines whether workers are informed even before receiving the Statement. The data are then matched to administrative records from the SSA to evaluate the effect of the Statement on retirement decisions.

The HRS is a longitudinal, biennial, nationally representative survey of older Americans. I use waves 1 to 6 (1992-2002), and restrict the analysis to workers older than age 55 and younger than age 70 who are not receiving Social Security disability benefits. I also restrict the sample to workers who are in the labor force in 1992, and drop workers from the sample if they die. I restrict the analysis to workers born between 1922 and 1941.40 Workers are matched with their spouses' information. Some workers have expected benefits that are smaller than half of the benefits of their spouse. These workers are excluded from the analysis since they are better off by claiming for their spouses' benefits, and are unlikely to respond to changes in their own SSW. Table13 in the Appendix shows the summary statistics for the HRS sample used in the regressions.

Table 13: Summary statistics

\begin{tabular}{lccc}
\hline \hline \multicolumn{1}{c}{ Variable } & Mean & Std. Dev. & N \\
\hline Age & 61.571 & 3.723 & 33118 \\
Female & 0.344 & 0.475 & 33118 \\
Married & 0.973 & 0.163 & 33118 \\
Work experience & 38.141 & 9.974 & 33118 \\
No children & 0.033 & 0.179 & 33118 \\
Black & 0.102 & 0.302 & 33118 \\
High School & 0.325 & 0.469 & 33118 \\
Some college & 0.207 & 0.405 & 33118 \\
College & 0.225 & 0.417 & 33118 \\
veteran & 0.374 & 0.484 & 33065 \\
SR health: very good & 0.347 & 0.476 & 33118 \\
SR health: good & 0.315 & 0.465 & 33118 \\
SR health: fair & 0.119 & 0.323 & 33118 \\
SR health: poor & 0.025 & 0.156 & 33118 \\
Independent spouse & 0.688 & 0.463 & 33118 \\
Spouse's age-own age & -0.515 & 3.113 & 33118 \\
Real AIME & 2243.795 & 1316.625 & 33118 \\
Spouse's real AIME & 1065.013 & 1288.846 & 33118 \\
\hline
\end{tabular}

${ }^{40}$ Some further deletions are made mostly for reasons of miscellaneous data inconsistencies. 
Figure 6: The Social Security Statement

\section{Your Estimated Benefits}

To qualify for benefits, you eam "credits" through your w ork - up to four each year. Th is year, for exam ple, you eam one credit for each $\$ 900$ ofw ages or selfem ploym ent incom e.W hen you 've eamed $\$ 3,600$, you 've eamed your four credits for the year.M ost people need 40 credits, eamed over their w orking lifetm e, to receive retirem ent benefits. For disability and survivors benefits, young people need few er credits to be eligible.

W e checked your records to see w hether you have eamed enough credits to qualify for benefits. If you haven teamed enough yet to qualify for any type of benefilt, we can t give you a benefit estim ate now. If you continue to w ork, well give you an estim ate when you do qualify.

What we assumed- If you have enough w ork credits, we estim ated your benefil am ounts using your average eamings over your w orking lifetim e. For 2004 and later (up to retirem entage), we assum ed you 'llcontinue to w ork and $m$ ake about the sam e as you did in 2002 or 2003. W e also included credits we assum ed you eamed last year and this year.
W e can t provide your actual benefit am ount untilyou apply for benefits. And that amount may differ from the estimates stated below because:

(1) Your earnings may increase or decrease in the future.

(2) Your estim ated benefits are based on current law.

The law governing benefit amounts may change. *

(3) Your benefit am ountm ay be affected by military service, railroad employment or pensions earned through work on which you did not pay Social Security tax. Visit www.socialsecurity.gov/mystatement to see whether your Social Security benefit amount will be affected.

Generally, estim ates for older w orkers are $m$ ore accurate than those for younger w orkers because they're based on a longer eamings history w ith few er uncertainties such as eamings fluctuations and future law changes.

These estim ates are in today's dollars. After you start receiving benefits, they w ill be adjusted for cost-of living increases. $\nabla$ * Retirement

$\nabla$ * Disability

$\nabla$ *Family

$\nabla$ * Survivors

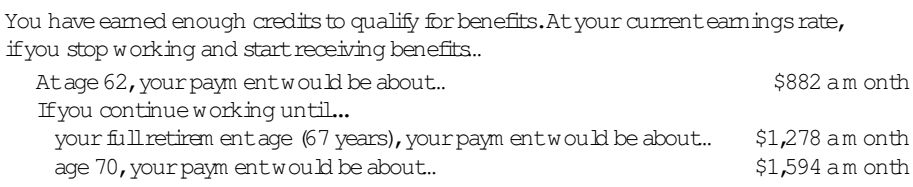

You have eamed enough credits to qualify for benefits. At your current eamings rate, if you stop w orking and start receiving benefits.

Atage 62, your paym entw ould be about.

Ifyou continue w orking until..

your fill retirem ent age (67 years), your paym entw ould be about.. $\quad \$ 1,278$ a m onth age 70 , your paym entw ould be about..

You have eamed enough credits to qualify for benefits. If you becam e disabled right now, Your paym ent w ould be about..

$\$ 1,169$ a m onth

If you get retirem ent or disability benefits, your spouse and children also m ay qualify for benefits.

You have eamed enough credits for your fam ily to receive survivors benefits. If you die this year, certain $m$ em bers of your fam ily may qualify for the follow ing benefits.

Your child.

Your spouse who is caring for your child.

$\$ 911$ a m onth

Your spouse, if fenefits start at fill retirem ent age. _ \$1,215 a m onth

Total fam ily benefits cannot be $m$ ore than... $\quad \$ 2,233$ am onth

Your spouse or m inor child $m$ ay be eligible for a specialone-tim e death benefit of $\$ 255$.

$\nabla$ Medicare

You have enough credits to qualify for M edicare at age 65. Even ifyou do not retire at age 65 , be sure to contact SocialSecurity three $m$ on ths before your 65th birthday to enroll in M edicare.

* Your estimated benefits are based on current law. Congress has made changes to the law in the past and can do so at any time. The law governing benefit amounts may change because, by 2042, the payroll taxes collected will be enough to pay only about 73 percent of scheduled benefits

$\begin{array}{ll}\text { We based your benefit estimates on these facts: } & \\ \text { Your nam e... } & \text { W anda W orker } \\ \begin{array}{l}\text { Your date ofbirth ... } \\ \text { Your estim ated taxable eamings } \\ \quad \text { per year after 2003... }\end{array} & \text { M ay 5, 1963 } \\ \text { Your Social.Security num ber (only the lastfour digits } & \$ 35,051\end{array}$

are shown to help prevent identity theft)..

$\mathrm{XXX}-\mathrm{XX}-2004$ 


\section{Help Us Keep Your Earnings Record Accurate}

You, your em ployer and Social Security share respon sibility for the accuracy of your eamings record. Since you began w orking, we recorded your reported eamings under your nam e and Social Security num ber. We have updated your record each tim e your em ployer (or you, ifyou re self-em ployed) reported your eamings.

Rem em ber, it's your eamings, not the am ount of taxes you paid or the num ber of credits you 've eamed, that determ ine your benefit am ount. $W$ hen we figure that am ount, we base it on your average eamings over your lifetim e. Ifour records are w rong, you m ay not receive all the benefits to which you 're entitled.

$\boldsymbol{\nabla}$ Review this chart carefully using your ow $n$ records to $\mathrm{m}$ ake sure our inform ation is correct and that we've recorded each year you w orked. You are the only person who can look at the eamings chart and know whether it is com plete and correct.

Som e or allofyour eamings from last year $m$ ay not be shown on yourStatement. It could be thatwe still were processing last year's eam ings reports when your Statement was prepared. Your com plete eamings for last year w ill be show $n$ on next year's Statement . Note: Ifyou w orked form ore than one em ployer during any year, or ifyou had both eamings and selfem ploym ent incom e, we com bined your eamings for the year.

$\nabla$ There's a limit on the amount of earnings on which you pay Social Security taxes each year. The Im it increases yearly. Eamings above the Im itw ill not appear on your eamings chart as Social Security eamings. (For M edicare taxes, them axim um eamings am ountbegan rising in 1991. Since 1994, all of your eamings are taxed for $\mathrm{M}$ edicare.)

$\nabla$ Call us right away at 1-800-772-1213 $7 \mathrm{am} .-7 \mathrm{pm}$. your local tim e) if any eamings for years before last year are shown incorrectly. If possible, have yourw -2 or tax retum for those years available. (Ifyou live outside the U S ., follow the directions at the bottom of page 4.)

Your Earnings Record at a Glance.

\begin{tabular}{ccc|} 
Years You & Your Taxed & Your Taxed \\
Wocialsecurity & $\begin{array}{c}\text { Medicare } \\
\text { Eamings }\end{array}$ \\
1979 & Eamings & 474 \\
1980 & 474 & 1,123 \\
1981 & 1,123 & 1,983 \\
1982 & 1,983 & 3,293 \\
1983 & 3,293 & 4,461 \\
1984 & 4,461 & 5,600 \\
1985 & 5,600 & 6,950 \\
1986 & 6,950 & 8,813 \\
1987 & 8,813 & 10,941 \\
1988 & 10,941 & 12,803 \\
1989 & 12,803 & 14,520 \\
1990 & 14,520 & 16,308 \\
1991 & 16,308 & 17,920 \\
1992 & 17,920 & 19,655 \\
1993 & 19,655 & 20,534 \\
1994 & 20,534 & 21,730 \\
1995 & 21,730 & 23,155 \\
1996 & 23,155 & 24,838 \\
1997 & 24,838 & 26,806 \\
1998 & 26,806 & 28,720 \\
1999 & 28,720 & 30,824 \\
2000 & 30,824 & 33,060 \\
2001 & 33,060 & 34,237 \\
2002 & 34,237 & 35,051 \\
2003 & 35,051 & \\
& Not yetrecorded &
\end{tabular}

Did you know... Social Security is more than just a retirement program? It's here to help you when you need it most.

You and your fam ily $m$ ay be eligible for valuable benefits:

$\boldsymbol{\nabla}$ w hen you die, your fam ily m ay be eligible to receive survivors benefits.

$\boldsymbol{\nabla}$ socialsecuritym ay help you ifyou becom e disabled- even at a young age.

$\boldsymbol{\nabla}$ It is possible for a young person who has w orked and paid Socialsecurity taxes in as few as two years to becom e eligible for disability benefits.

Socialsecurity credits you eam $m$ ove $w$ ith you from jo to jpb throughout your career.

Total Social Security and Medicare taxes paid over your working career through the last year reported on the chart above: Estim ated taxes paid for Social.Security: You paid: $\$ 24,723$ Estim ated taxespaid for M edicare:

Your em ployers paid: $\quad \$ 24,723$ You paid: $\$ 5,820$

Note: You currently pay 6.2 percent of your salary, up to $\$ 87,900$, in Social Security taxes and 1.45 percent in Medicare taxes on your entire salary. Your employer also pays 6.2 percent in Social Security taxes and 1.45 percent in Medicare taxes for you. If you are self-employed, you pay the combined employee and employer amount of 12.4 percent in Social Security taxes and 2.9 percent in Medicare taxes on your net earnings. 


\section{Some Facts About Social Security}

\section{About Social Security and Medicare.}

Social.Security pays retirem ent, disability, fam ily and survivors benefits. M edicare, a separate program run by the Centers for M edicare and M edicaid Services, helps pay for inpatient hospital care, nursing care, doctors' fees, and otherm edicalservices and supplies to people age 65 and older, or to people who have been receiving Socialsecurity disability benefits for tw o years or m ore. Your Socialsecurity covered eamings qualify you for both program s.

Here are some facts about Social Security's benefits:

$\boldsymbol{\nabla}$ Retirement- Ifyou were bom before 1938, your

full retirem ent age is 65 . Because of a 1983 change in the law, the full retirem ent age $w$ ill increase gradually to 67 for people bom in 1960 and later.

Som e people retire before their fill retirem ent age. You can retire as early as age 62 and take your benefits at a reduced rate. If you continue w orking after your full retirem ent age, you can receive $h$ igher benefits because of additionaleamings and special credits for delayed retirem ent.

$\boldsymbol{\nabla}$ Disability- Ifyou becom e disabled before full retirem ent age, you can receive disability benefits after sixm onths ifyou have:

- enough credits from eamings (depending on your age, you m ust have eamed six to 20 of your credits in the three to 10 years before you becam e disabled); and

- a physicalorm entalim pairm ent that is expected to preventyou from doing "substantial" work for a year orm ore, or result in death.

$\boldsymbol{\nabla}$ Family- If you 're eligible for disability or retirem ent benefits, your current or divorced spouse, $m$ inor children, or adu It children disabled before age 22 also $m$ ay receive benefits. Each $m$ ay qualify for up to about 50 percent of your benefit am ount. The total am ount depends on how $m$ any fam ily $m$ em bers qualify.

$\nabla$ Survivors - $W$ hen you die, certain $m$ em bers of your fam ily $m$ ay be eligible for benefits:

- your spouse age 60 or older (50 or older if disabled, or any age if caring for your children younger than age 16); and

- your children ifunm arried and younger than age 18, still in schooland younger than 19 years old, or adult chiblren disabled before age 22 .

If you are divorced, your ex-spouse could be eligible for a w idow 's or w idow er's benefit on

your record when you die.

If you need more information-Visitwww.socialsecurity.gov/mystatement on the Intemet, contact any Social.Security office, call 1-800-772-1213 or w rite to Social.Security Adm in istration, O ffice of E amings O perations, P.O . B ox 33026, $\mathrm{Baltim}$ ore, M D 21290-3026. Ifyou 're deafor hard of hearing, call TTY 1-800-325-0778. If you have questions about your personal in form ation, you m ust provide your com plete Social. Security num ber. Ifyour address is incorrect on this Statem ent, ask the IntemalRevenue Servioe to send you a Form 8822.W e don tkeep your address if you re not receiving Socialsecurity benefits.

Para solicitar una Declaración en español, llame al 1-800-772-1213.
Receive benefits and still work.

You can continue to work and stillget retirem entor survivors benefits. If you 're younger than your full ent age, there are lim its on how $m$ uch you can eam $w$ ithout affecting your benefit am ount. The lim its change each year. W hen you apply for benefits, well tell you what the im its are at that tim e and whether w ork wild affect yourm onthly benefits.W hen you reach fill Before you decide to retire..

Think about your benefits for the long term. Everyone's situation is different. For exam ple, be sure to consider the advantages and disadvantages of early retirem ent. If you choose to receive benefits before you reach full retirem ent age, your benefits w ill be perm anently reduced. H ow ever, you lil receive benefits for a longer period oftim e.

To help you decide when is the best tim e for you to retire, we offer a free booklet, Social Security-

Retirement Benefits (Publication No.05-10035), that provides specific in form ation about retirem ent. You can calcu late future retirem entbenefits on our w ebsite twww.socialsecurity.gov by using the Social Security Benefit Calculators. There are other free publications that you $m$ ay find helpful, including:

V Understanding The Benefits (No.05-10024)- a general explanation of all.Socialsecurity benefits;

$\nabla$ How Your Retirement Benefit Is Figured (No.05-10070)- an explanation of how you can calcu late your benefit;

$\nabla$ The Windfall Elimination Provision (No.05-10045)how it affects your retirem ent or disability benefits;

$\boldsymbol{\nabla}$ Government Pension Offset (No.05-10007)explanation ofa law that affects spouse's or w idow (er)'s benefits; and

$\nabla$ When Someone Misuses Your Number (No.05-10064)what to do ifyou re a victim of identity theft.

W e also have other leaflets and fact sheets $w$ ith inform ation about specific topics such as m ilitary service, selfem ploym ent or foreign em ploym ent. You can request Social Security publications at

1-800-772-1213 


\section{RECENT WORKING PAPERS FROM THE}

\section{CENTER FOR RETIREMENT RESEARCH AT BOSTON COLLEGE}

Social Security and the Joint Trends in Labor Supply and Benefits Receipt Among Older Men

Bo MacInnis, October 2009

The Wealth of Older Americans and the Sub-Prime Debacle

Barry Bosworth and Rosanna Smart, October 2009

The Asset and Income Profile of Residents in Seniors Care Communities

Norma B. Coe and Melissa Boyle, September 2009

Pension Buyouts: What Can We Learn From the UK Experience?

Ashby H.B. Monk, September 2009

What Drives Health Care Spending? Can We Know Whether Population Aging is a 'Red Herring'?

Henry J. Aaron, September 2009

Unusual Social Security Claiming Strategies: Costs and Distributional Effects Alicia H. Munnell, Steven A. Sass, Alex Golub-Sass, and Nadia Karamcheva, August 2009

Determinants and Consequences of Moving Decisions for Older Homeowners Esteban Calvo, Kelly Haverstick, and Natalia A. Zhivan, August 2009

The Implications of Declining Retiree Health Insurance

Courtney Monk and Alicia H. Munnell, August 2009

Capital Income Taxes With Heterogeneous Discount Rates

Peter Diamond and Johannes Spinnewijn, June 2009

Are Age-62/63 Retired Worker Beneficiaries At Risk?

Eric R. Kingson and Maria T. Brown, June 2009

Taxes and Pensions

Peter Diamond, May 2009

How Much Do Households Really Lose By Claiming Social Security at Age 62?

Wei Sun and Anthony Webb, April 2009 